\title{
Dutch or Iranian? Technical study of a seventeenth-century painting on paper from Gesina Ter Bosch's scrapbook
}

\author{
Amélie Couvrat Desvergnes ${ }^{1 *}\left(\mathbb{0}\right.$, Leila Sauvage ${ }^{2}$, Jan de Hond ${ }^{3}$, Paolo D'Imporzano ${ }^{4}$ and Matthias Alfeld ${ }^{5}$
}

\begin{abstract}
A scrapbook compiled between 1660 and 1687 by Gesina ter Borch (1631-1690), a female artist from the small town of Zwolle in the Netherlands, contains an intriguing painting on paper of a full-length portrait of a young Iranian. Although the figure wears the attributes in vogue at the Safavid court of Isfahan, certain elements seem rather incongruous and peculiar. The general composition appears static and rigid, an impression reinforced by an unusual black painted background. Stylistic differences within the painting were also observed, hinting at alterations to the original painting. To investigate the history of the painting and to reconstruct the original composition and identify the later additions, perhaps made by Gesina herself, the painting was examined with different imaging and analytic techniques available at the Conservation and Science Department of the Rijksmuseum. This allowed the research team to discriminate between pigments used for the original composition and pigments used to conceal damaged areas of the painting and added pictorial elements. After interpreting scientific results, as well as historical findings, it was possible to shed light on the use of specific pigments, namely lead white and smalt, and on the possible misinterpretation of some details, such as the cup held by the young man. The results of macro X-ray fluorescence scanning (MA-XRF) and lead isotope analysis, viewed in the light of information about the economic and cultural exchanges between Iran and the Netherlands in the seventeenth century, fed new theories about the origin and history of this painting. The painting, originally made in Iran in the style of Riza Abbasi, the head of the Emperor Shah Abbas'library, ended up in Gesina ter Borch's workshop and may have been 'restored' by the artist to improve its condition and to match her tastes.
\end{abstract}

Keywords: Gesina ter Bosch, Dutch painting, Iranian painting, Safavid painting, Macro-XRF, Micro-XRF, Lead isotope, Pigment identification, Smalt, Lead white, HIROX-RH 2000

\section{Introduction}

The Rijksmuseum has been the keeper of the Ter Borch family's studio estate since 1890. Part of this estate is the so-called family scrapbook (acquisition number BI-1887-1463), owned and compiled by Gesina ter Borch
(1631-1690), daughter of the well-known Dutch painter Gerard ter Borch and a woman of many talents in her own right [1]. Although as a woman she could not expect to pursue a career as a professional artist, she practiced the arts throughout her life: calligraphy at first, then

*Correspondence: ameliecd@gmail.com

${ }^{1}$ Utrecht, The Netherlands

Full list of author information is available at the end of the article

Springer Open

(c) The Author(s) 2021. Open Access This article is licensed under a Creative Commons Attribution 4.0 International License, which permits use, sharing, adaptation, distribution and reproduction in any medium or format, as long as you give appropriate credit to the original author(s) and the source, provide a link to the Creative Commons licence, and indicate if changes were made. The images or other third party material in this article are included in the article's Creative Commons licence, unless indicated otherwise in a credit line to the material. If material is not included in the article's Creative Commons licence and your intended use is not permitted by statutory regulation or exceeds the permitted use, you will need to obtain permission directly from the copyright holder. To view a copy of this licence, visit http://creativecommons.org/licenses/by/4.0/. The Creative Commons Public Domain Dedication waiver (http://creativeco mmons.org/publicdomain/zero/1.0/) applies to the data made available in this article, unless otherwise stated in a credit line to the data. 


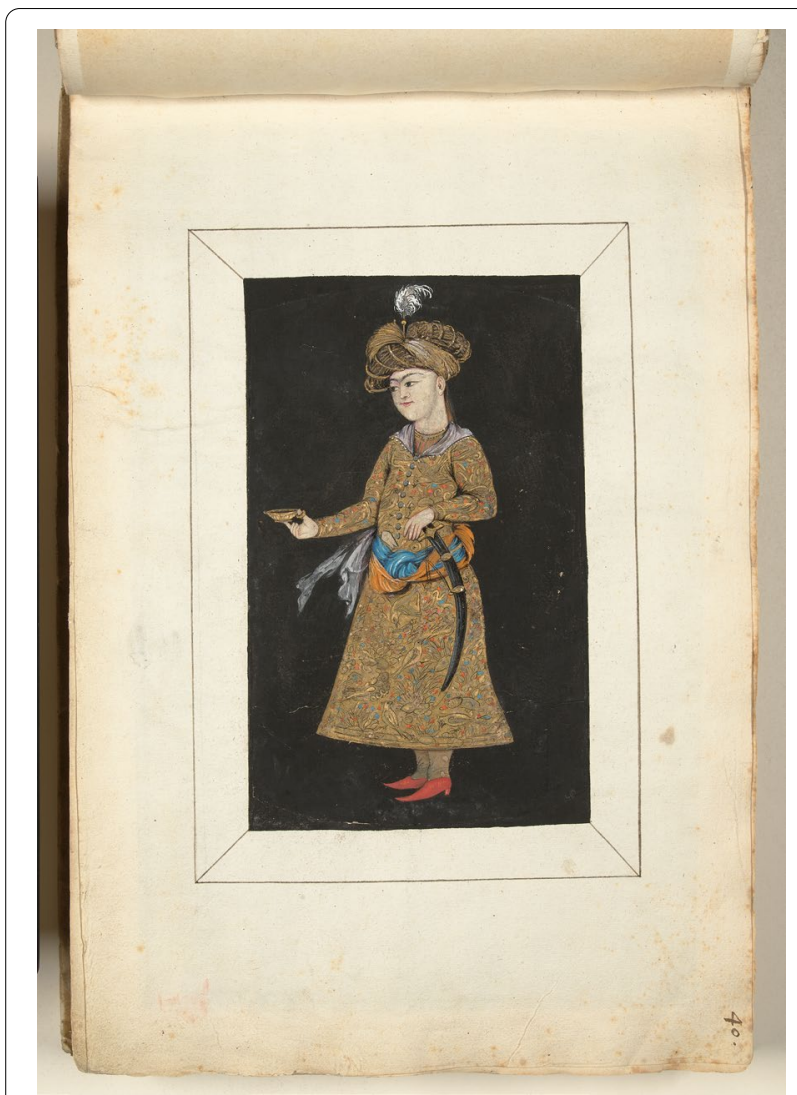

Fig. 1 An Iranian Youth, c. 1650-70, from Gesina ter Borch's family scrapbook, fol. 40r. Opaque watercolour heightened with gold and silver on paper, Rijksmuseum, dimensions of the album page 243 mm × 360 m, Amsterdam, Rijksmuseum, inv. no. BI-1887-1463-40; purchased with the support of the Vereniging Rembrandt

primarily drawing and painting [2]. ${ }^{1}$ Gesina started the scrapbook in the 1660 s. She originally intended to fill the blank pages of the album with her own watercolour drawings of everyday scenes from Zwolle, a provincial town in the eastern part of the Netherlands where she was born. As time went by, she changed the concept of her book. She stopped drawing straight onto the album pages and began pasting in separate drawings insteadher own work, and that of her father and brothers as well. In the end, a diverse mix of other items appeared in the album: examples of calligraphy, children's drawings by nephews and nieces, works by other artists and copies after other masters. ${ }^{2}$

\footnotetext{
${ }^{1}$ An article by De Hond et al., published in 2020 in the Rijksmuseum Bulletin, details the artistic and historical context of the Iranian Youth.

2 The drawings are available on https://www.rijksmuseum.nl/nl/collectie/ BI-1887-1463 (last visited 28/05/2021).
}

Page 40 of the album (acquisition number BI-18871463-40), the subject of the present study, is the only sheet with a non-European subject and features a unique painting: a portrait of an Iranian Youth (Fig. 1). A blackand-white photograph of the Iranian Youth was included in a 1988 catalogue raisonné [1], but the sheet was never mentioned or reproduced again in later literature.

The subject and composition of the young Iranian man are entirely in the seventeenth-century tradition of Safavid painting in Iran. However, several stylistic and technical aspects of the composition, which will be described in the following section, raised questions about the provenance and possible alterations of the painting. Is it an original Safavid miniature or the product of a Western artist? Or is it both: an original Iranian painting with later Western additions? And if so, which parts are original and which ones are alterations? Is it possible to identify the original Iranian painter and the artist who was responsible for the later additions?

No documentation exists for conservation treatments or retouching on the scrapbook after it entered the Rijksmuseum collection, so any alterations would most likely predate 1890. Close examination also suggests that the album and the works it contains have not been altered or restored from the moment of the scrapbook's completion until the moment the Ter Borch family estate was transferred to the Rijksmuseum. Could the artist responsible for the alterations then be Gesina herself? And what are plausible reasons for these overpaintings? Analytical data, in combination with technical and historical information, were used to identify the pigments that were likely used and to reconstruct the painting's stratigraphy and possible chronology, and so gain a better understanding of this intriguing artistic encounter between Iran and the Dutch Republic.

\section{Description of the painting, relations to the Gesina's scrapbook, Safavid art and areas of special interest}

Safavid miniatures were initially part of costly manuscripts worked on by various artists. They usually took literary themes as their subjects and were made in court workshops (libraries), where calligraphers and painters worked closely together on often very large manuscripts. Over the course of the sixteenth and seventeenth centuries artistic practices evolved and Iranian painters no longer worked exclusively for rulers and princes, but increasingly produced works for the open market of the urban elite [3-5]. This change in clientele had consequences for the form as well as the content of the artworks produced. Instead of expensive manuscripts, Iranian artists more often made loose sheets with subjects that appealed to the tastes of the emerging elite of 
merchants and officials: scenes from urban life, visitors from Europe, travelling dervishes and, above all, illustrations of elegant young men and women relaxing with music, wine and one another's company [6]. One of the best-known artists to specialize in the genre was Riza Abbasi (1565-1635), Shah Abbas' favourite artist. The artist was attached to the royal workshop for the greater part of his career, but also worked for an elite clientele outside the palace walls [3]. He and his followers of the Isfahan School made paintings of Iranian jeunesse dorée-of which the Iranian Youth in Gesina's album, with his opulent clothes and a wine dish in his hand, is a perfect example-extremely popular. Riza Abbasi himself painted a Young Man with Three Cups, dated to 1629 (Fig. 2a). It is obvious that the tray, the posture of the body and the headgear are different from the image in Gesina's scrapbook, but the pattern of the dress, with the combination of birds, rocks and vegetation, is similar. His pose and dress more closely resemble that of the Cupbearer on a miniature, now in the Bibliothèque Nationale de France $(\mathrm{BnF})$. It was previously attributed to Riza Abbasi, but is now considered to be the work of a midseventeenth-century follower (Fig. 2b).

The Youth in a Red Coat, dated circa 1630-50, in the collection of the Aga Khan Museum in Toronto, seems to fit the style of Riza Abbasi more closely, given Youth's elegance and his gracious pose, with a slightly bowed head (Fig. 2c) [7]. Like the BnF sheet, this miniature differs in several details from the drawing in Gesina's scrapbook. For instance, the man in the Toronto miniature has sideburns and carries a pouch. The most striking difference, however, is his plain red coat instead of the gold dress with the bird pattern in Gesina's scrapbook. In 2019, a miniature much closer in composition to the one in Gesina's scrapbook was auctioned at Christie's in London (Fig. 2d). For stylistic reasons, this painting can probably be dated to the mid-seventeenth century or a little later. ${ }^{3}$ There are notable similarities: both men wear similar dresses with bird motifs and neither has side whiskers, which is rare in Safavid art from this period. Several elements, however, differ from the young man in Gesina's album: the shape of his coat (an extra fold on the left that is not present in Gesina's figure) and the pattern on the garment (the position of the birds' heads on the sleeves). In addition, there is an intriguing difference between

\footnotetext{
${ }^{3}$ With thanks to Massumeh Farhad for the revised dating and identification. In Art of the Islamic and Indian Worlds, auction cat. London (Christie's), 24 October 2019, no. 54. The miniature is dated to the end of the sixteenth century, but this was revised to the mid-seventeenth century during the auction.
}

the drinking bowls on the painting from Gesina's scrapbook and the Iranian miniature painting auctioned by Christie's. On Gesina's, the bowl has a handle through which the youth has placed his thumb. Drinking bowls with handles, however, do not exist in Iranian art of this period. The man in the Christie's miniature holds a bowl without a handle and wears a thumb ring.

The most striking differences with Gesina's sheet are the scrapbook miniature's plain black background and the colourful sashes around the young man's waist. No similar black background was found in the rest of the album, nor in Iranian miniatures so far. Usually, the backgrounds in Iranian miniatures of this period are simple; the paper is left in reserve and some stylized landscapes are painted with gold or sepia, like in the Christie's miniature.

The colourful blue and orange sashes around the young man's waist, the feather on the turban and the white collar on the miniature in Gesina's scrapbook are also conspicuous. These details are very different from the rest of the drawing; they were painted much more loosely, with a clearly visible brushstroke and striking white highlights. The three-dimensional effect contrasts sharply with the much flatter rendering of the rest of the figure. The sashes are stylistically close to the sashes that Gesina painted on other drawings in the scrapbook, for example in the portrait of her brother Moses (Fig. 3).

Furthermore, the format of the original support seems to have been altered. Close examination revealed that its upper and lower edges are rounded and that the lower right corner is missing (Fig. 4). The design is now rectangular and surrounded by ruled lines drawn with cut angles to mimic a frame. Similar frames surround other drawings in the album such as the two portraits of a lord standing by a river and a man walking, both drawn by Harmen ter Borch, pasted in the same way by Gesina (Fig. 5). ${ }^{4}$

Finally, the face is roughly rendered here and the pose is rather static. In short, the figure appears less refined and more mechanical unlike the graceful, almost calligraphic outlines of the miniature of Christie's and the works of Riza Abbasi. The strong shading effect around the folds near the arm and upper body is also striking: it gives an impression of three-dimensionality which is absent in the Iranian originals.

\footnotetext{
${ }^{4}$ Gesina used similar framed lines to surround the drawings of a Reading Woman (after Rembrandt), the Holy Family by Moses ter Borch (after Abraham Bloemaert), a Turkey by an unknown artist, a Tulip from Anna Cornelia Moda, two Women's Heads and a Portrait of Gerard ter Borch the Elder, Moses ter Borch, Still Life with Flowers, a Head and a Bust of a Man, by Machtelt Moninckx and by Moses ter Borch (after Rembrandt).
} 

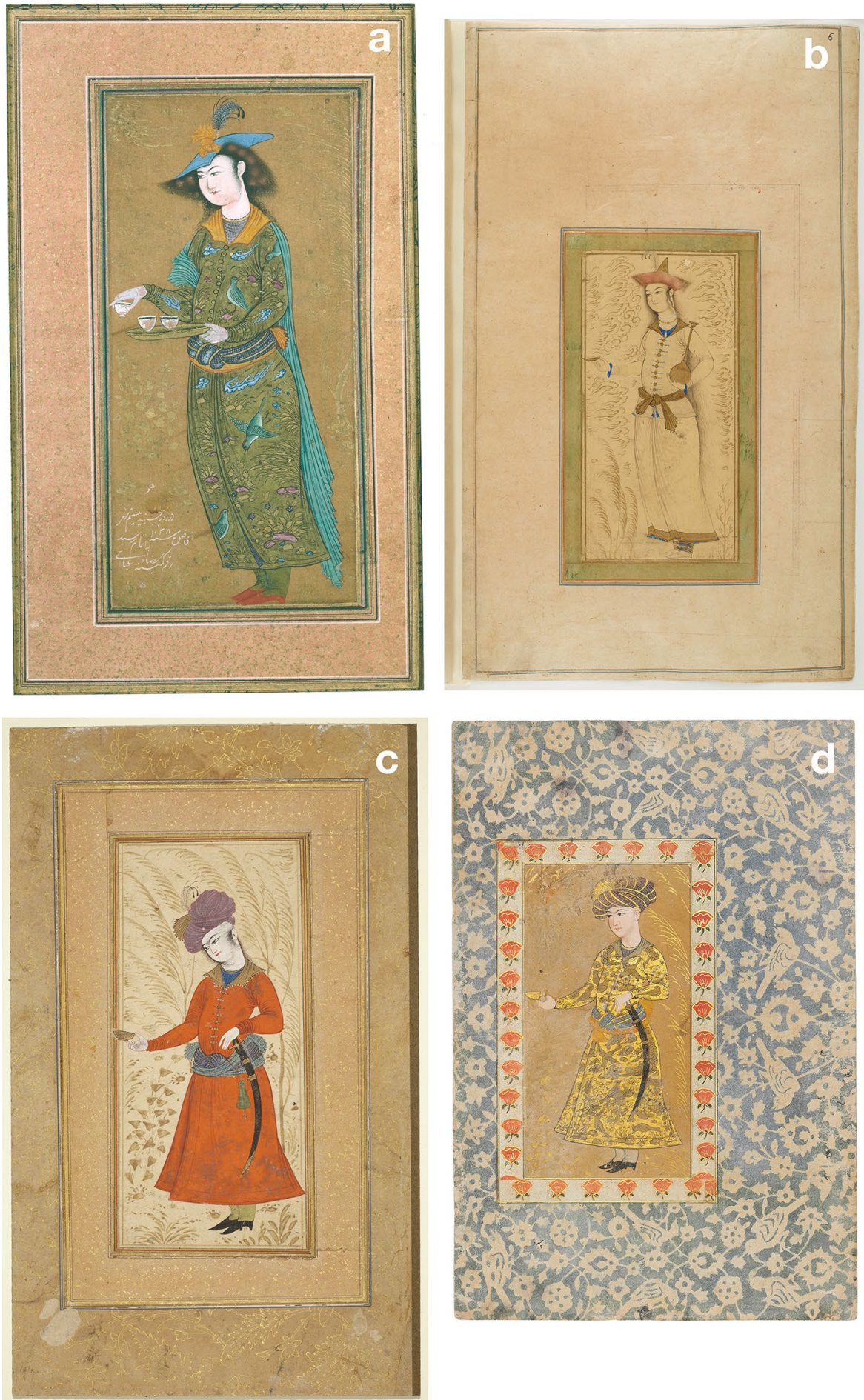

Fig. 2 a Riza Abbasi, Young Man with Three Cups, 1629. Pigments on paper, $181 \times 92 \mathrm{~mm}$. Prince and Princess Sadruddin Aga Khan Collection. b Cupbearer, follower of Riza Abbasi, mid seventeenth century, from the album containing works by Riza Abbasi. Pigments on paper, $288 \times 133 \mathrm{~mm}$. Paris, Bibliothèque nationale de France, Département des Manuscrits, Supplément Persan 1572, folio 7r. c Youth in a Red Coat, c. 1630-50, Safavid Iran. Opaque watercolour and gold on paper, $108 \times 188 \mathrm{~mm}$ (sheet), $183 \times 83 \mathrm{~mm}$ (illustration). ( ) Toronto Aga Khan Museum, inv. no. AKM 436. d A Youth Holding a Wine Cup, c. 1650-70, Isfahan school. Opaque watercolour heightened with gold on paper, $173 \times 90$ mm (painting), $330 \times 223 \mathrm{~mm}$ (folio). Private collection. Photograph: @ Christie's Images/Bridgeman Images 


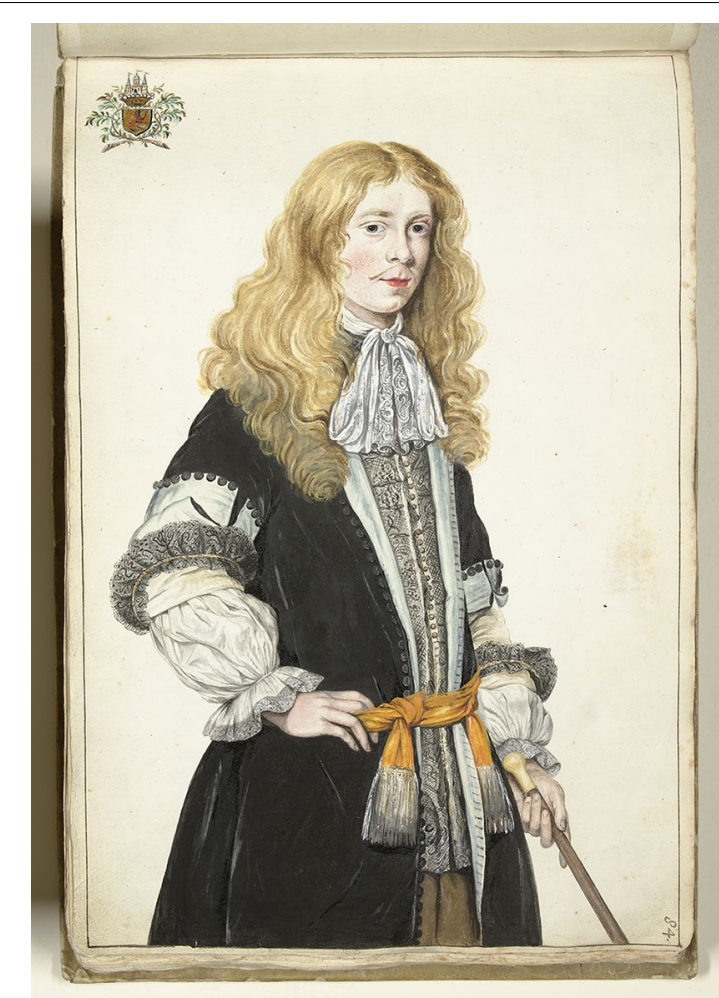

Fig. 3 Gesina ter borch, Portrait of Moses ter Borch, c. 1670, from Gesina ter Borch's family scrapbook, fol. 84r. Opaque watercolour on paper, $243 \times 360 \mathrm{~mm}$. Amsterdam, Rijksmuseum, inv. no. BI-1887-1463-84; purchased with the support of the Vereniging Rembrandt
These observations suggest that Gesina altered and retouched the image. The fact that she often made changes to the drawings of other artists in her scrapbook makes this a plausible hypothesis. ${ }^{5}$ To investigate the painting further, it was closely examined with high-resolution 3D digital microscopy. To identify the pigments used and to discriminate between original layers and later alterations, several non-invasive analytical techniques were used. For more information about the provenance of the painting, lead isotope analysis was carried out on microsamples of lead white taken from the painting.

\section{Experimental methods}

\section{High-resolution visible 3D digital microscopy (Hirox} RH-2000)

The painting was examined using the Hirox RH-2000 $3 \mathrm{D}$ digital microscope on a motorised 'bridge' stand

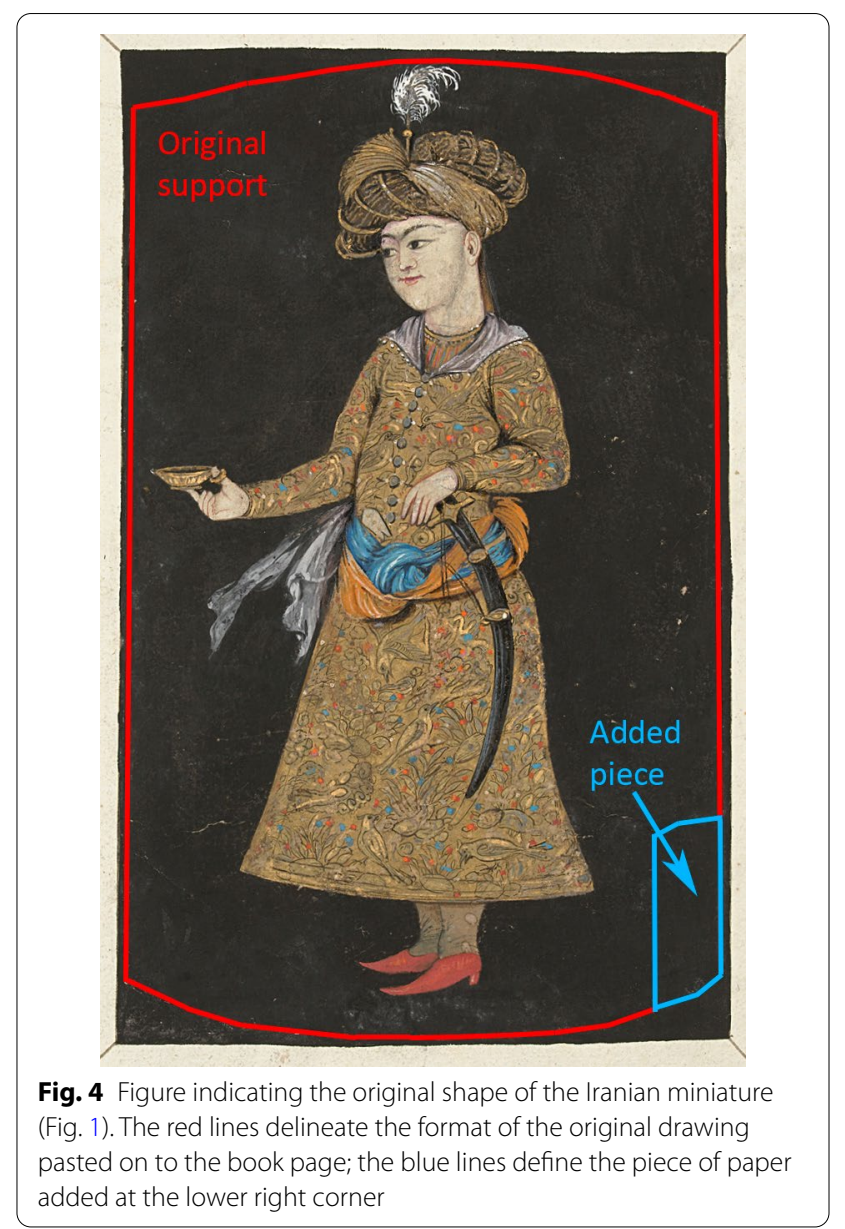

with a $500 \times 500 \mathrm{~mm}$ automatic motorised $\mathrm{XY}$ stage (200 nm steps). The microscope zoom lens MXB5000REZ was mounted on the Hirox FB-E Z-axis block with $30 \mathrm{~mm}$ motorised movement (50 $\mathrm{nm}$ steps). The CMOS camera captures up to 50 frames per second with the continuous high-quality resolution of $1920 \times 1200$ pixels. In addition to observation, the RH-2000 offers accurate and calibrated measurements in real-time, including length, area, angle, diameter or automatic surface area and provides $3 \mathrm{D}$ model, point height measurement, profiling and volume and area measurements. Thanks to the $3 \mathrm{D}$ image rendering system, the images are captured at multiple planes with automatic Z-axis drive for precise image plane intervals and height information. The images were processed using HIROX software. The images were taken at $35 \times$ and $50 \times$ magnification.

\footnotetext{
${ }^{5}$ For examples of drawings by other artists which Gesina adapted later, see [1], vol. 2, pp. 632, 633 (fols. 42, 44, 45).
} 


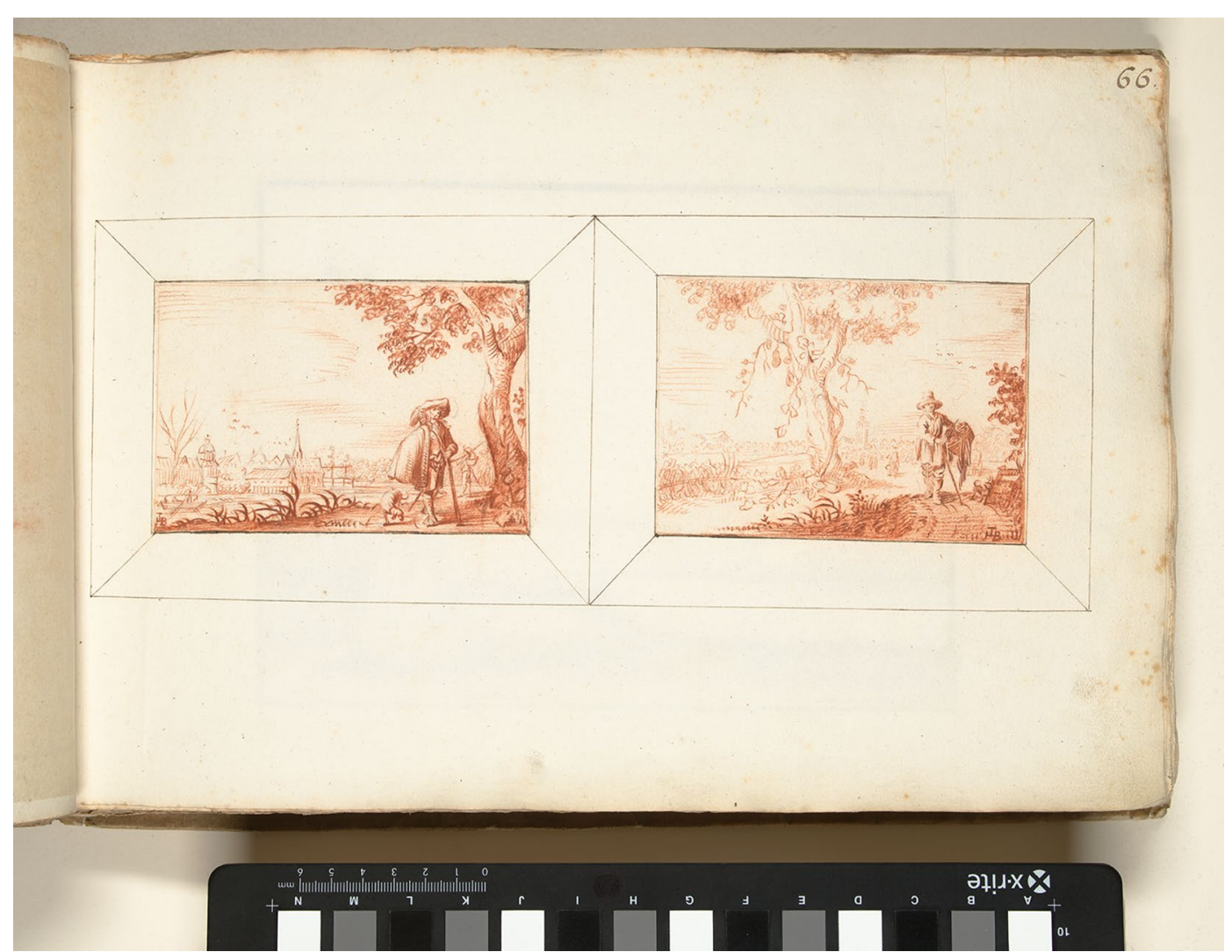

Fig. 5 Harmen ter Borch, Lord Standing on a River Bank and Walking Man, sanguine on paper, Amsterdam, Rijksmuseum, inv. no. BI-1887-1463-66; purchased with the support of the Vereniging Rembrandt

Close examination performed with the Hirox provided preliminary clues about the layers and stratigraphy of the paint. It remained used throughout the project as a visualization tool to verify the analytical results obtained.

\section{Infrared reflectography (IRR)}

The reflectographs were taken with an OSIRIS camera. The system is equipped with an InGaAs (indium gallium arsenide) detector, sensitive from 900 to $1700 \mathrm{~nm}$ and with a resolution of $4096 \times 4096$ pixels. A $150 \mathrm{~mm}$ lens, optimized for infrared imaging, is mounted on the camera. The lighting consists of two modular halogen lamps that emit IR without emitting too much heat. The integration time with slow scan was of $10 \mathrm{~ms}(50 \mathrm{~Hz}$ mains frequency) $8.3 \mathrm{~ms}$ ( $60 \mathrm{~Hz}$ mains frequency).

\section{Micro X-ray fluorescence ( $\mu$-XRF)}

$\mu$-XRF was carried out with the Brüker Artax 2.0 X-ray fluorescence spectrometer. It is equipped with a polycapillary lens, model MCBM 50-0,6 and a molybdenum tube, focus $0.05 \times 0.005 \mathrm{~mm}^{2}$. The setting for the measurements was made at voltage $50 \mathrm{kV}$, current $600 \mu \mathrm{A}$, live time $120 \mathrm{~s}$, without helium [8]. Because the painting was mounted into the album page, a thick poly(methyl methacrylate) sheet (around $5 \mathrm{~mm}$ ) was inserted below the page to avoid contamination from the following sheets.

\section{Fibre optic reflectance spectrometry (FORS)}

FORS was performed with the system ASD FieldSpec ${ }^{\circledR}$ marketed by Ocean Optics. It is a 4 Standard-Res portable spectrometer, optimized for the VIS-NIR (360$2000 \mathrm{~nm}$ ). It is equipped with three detectors: a VNIR detector (350-1000 nm), a SWIR detector 1 (1001$1800 \mathrm{~nm})$ and a SWIR 1 detector $2(1801-2500 \mathrm{~nm})$. The scanning time is at $100 \mathrm{~ms}$ and the probe was handled manually. For this project, FORS was used as a complementary method to confirm the presence of specific pigments, such as the blue.

\section{UV light digital imaging}

The digital photographs were taken with the camera Canon EOS 5D Mark III fitted with the two UV light inspection lamps, UV LED MOD 2.5, UV wavelength range $360-370 \mathrm{~nm}$, power $20 \mathrm{~W}$, supplied by UV Light Technology UK. 


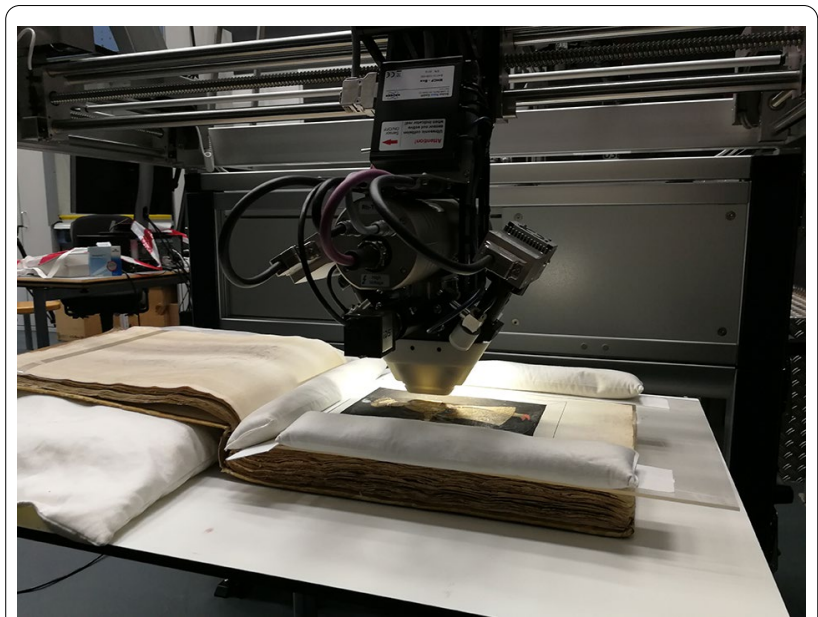

Fig. 6 View of the MA-XRF analytical setup used for the scrapbook. (C) Leila Sauvage, Rijksmuseum

\section{Macro X-ray fluorescence imaging (MA-XRF)}

Scanning Macro X-ray fluorescence imaging uses XRF for the acquisition of elemental distribution images. X-ray tube and detectors are mounted on a motorised stage and moved parallel to the surface in a regular grid, acquiring the image pixel by pixel and line by line. From the raw spectral data elemental distribution images are obtained in that a higher greyscale value indicates higher relative abundance. For this project a Bruker M6 Jetstream was used [9]. The Rh anode $\mathrm{X}$-ray tube was operated at $7.5 \mathrm{~W}(50 \mathrm{kV}, 150 \mu \mathrm{A})$ and a dwell time of $80 \mathrm{~ms} /$ pixel and a pixel size of $100 \mu \mathrm{m}$. The data was processed making use of PyMCA [10] and Datamuncher [11]. As the painting is mounted into an album (on page 40), the latter was securely kept open during the whole scanning process with blocks of foam and soft weight. A poly(methyl methacrylate) plate of about $5 \mathrm{~mm}$ was inserted behind the page to prevent contamination from other paintings during measurements (Fig. 6).

\section{Lead isotope analysis}

The samples were prepared for isotope analyses following the method described by D'Imporzano et al. 2020 [12]. In summary, the samples were dissolved in $\mathrm{HNO}_{3}$ and subsequently the lead fraction of the sample was extracted via liquid chromatography using $\mathrm{AG}^{\circledR} 1$-X8 anion exchange resin (analytical grade, 200-400 mesh, chloride form). The $\mathrm{Pb}$ sample solutions were then diluted to a concentration of $50 \mathrm{ppb}$ and analysed using a Thermo Fisher multi-collector-ICP-MS, equipped with a desolvating nebulizer system, CETAC Aridus II, using a standard sample bracketing method (SSB). A NBS981 lead solution, two in house internal-standards and a blank were analysed to monitor data quality. The

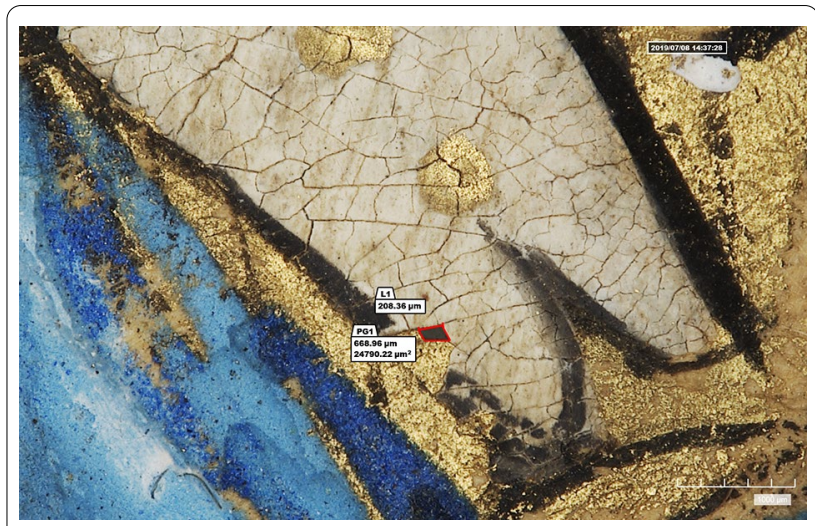

Fig. 7 Micrograph showing the location of the sample in the dagger for lead isotope analysis, HIROX RH-2000, 35X

blank solutions were prepared following the same procedure as the samples, and were used to monitor the amount of external lead introduced during the sampling and the sample preparation. Faraday cup detectors were assigned to the following masses: ${ }^{201} \mathrm{Hg} \mathrm{L} 4,{ }^{202} \mathrm{Hg} \mathrm{L} 3$, ${ }^{204} \mathrm{~Pb} \mathrm{~L} 2,{ }^{205} \mathrm{Tl} \mathrm{L} 1,{ }^{206} \mathrm{~Pb} \mathrm{C},{ }^{207} \mathrm{~Pb} \mathrm{H} 1,{ }^{208} \mathrm{~Pb} \mathrm{H} 2,{ }^{209} \mathrm{Bi} \mathrm{H} 3$. The long-term precision, expressed as 2 standard deviations (SD) over two years, was 0.0031 for ${ }^{206} \mathrm{~Pb} /{ }^{204} \mathrm{~Pb}$, 0.0034 for ${ }^{207} \mathrm{~Pb} /{ }^{204} \mathrm{~Pb}$ and 0.0114 for ${ }^{208} \mathrm{~Pb} /{ }^{204} \mathrm{~Pb}$.

The location of the micro-samples, the sampling procedure, the pros and cons of this invasive analytical method, and the outcome of the analysis were primarily discussed with the curator in charge of the object, the head of conservation, the conservators and the scientist. The sample locations were chosen in areas where the paint was already cracked and lifted up: in the hilt of the dagger (B.1887.146340-1) and in the left and right hands (B.1887.1463-40-2 and B.1887.1463-40-4). The main challenge was to take the smallest sample possible that was still large enough to allow the analysis of lead isotope ratios. Therefore, the sampling was done under the stereomicroscope using the MA-XRF $\mathrm{Pb}$ and $\mathrm{Ca}$ maps and the UV light image to ensure that only the lead white and no calcite were sampled. Photography with the HIROX-RH 2000 allowed us to accurately measure the sample size (Fig. 7). ${ }^{6}$

\section{Results \\ Optical observations and visual analysis Examination under high magnification Hirox $\mathrm{RH}-2000$}

Many small details that were not visible to the naked eye became visible under magnification, such as highlights in the dress and the buttons made with silver paint

\footnotetext{
${ }^{6}$ For example, the sample in the hilt of the dagger was $208.36 \mu \mathrm{m}$ long. The sampling was made with the help of a microscalpel and a thin brush, under the stereomicroscope and the whole information was recorded in a sample form.
} 

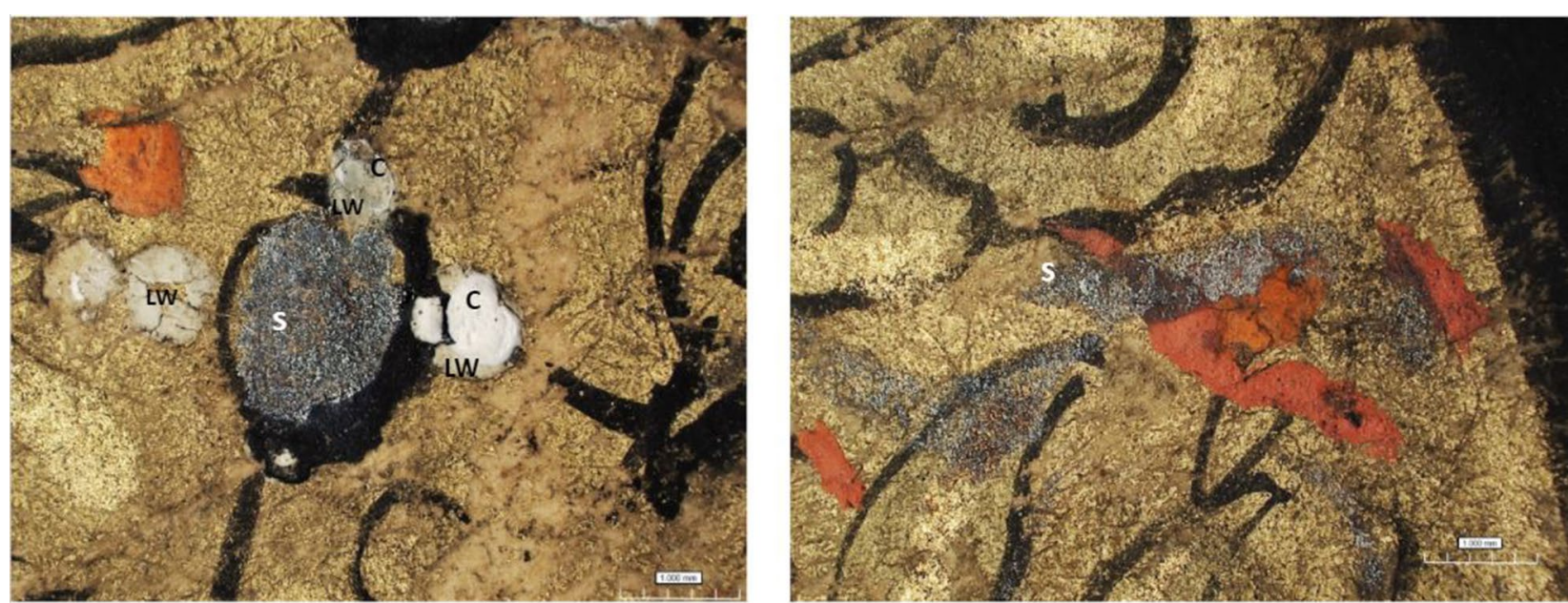

Fig. 8 Details of the Iranian Youth's dress. Left: S silver button, LW lead white dot, C calcite dot. Right: S the silver paint has blackened the underlying red and orange pigments

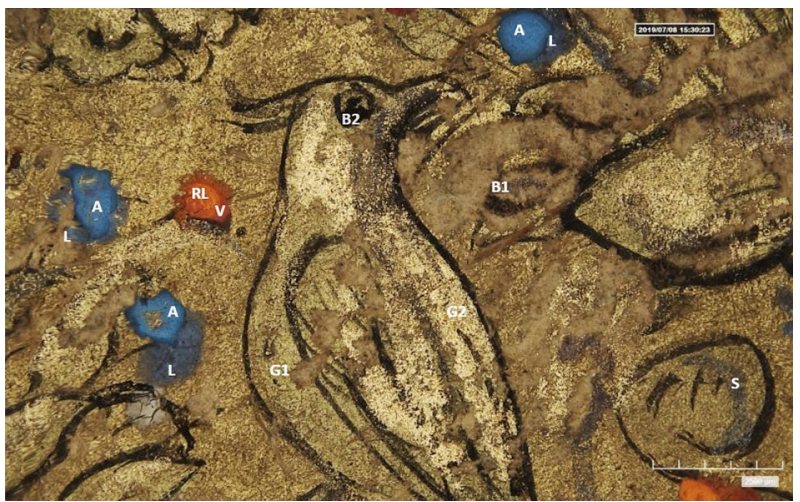

Fig. 9 Detail of the Iranian Youth's dress: L light and greyish blue, A bright blue, G1 Gold I, G2 Gold II, V and vermilion and RL red lead dots, B1 Black I, B2 Black II, S silver

(Fig. 8). In some areas of the dress, the silver paint covers the blue, red and orange dots and black outlines. As a result, the silver paint blackened the underlying red

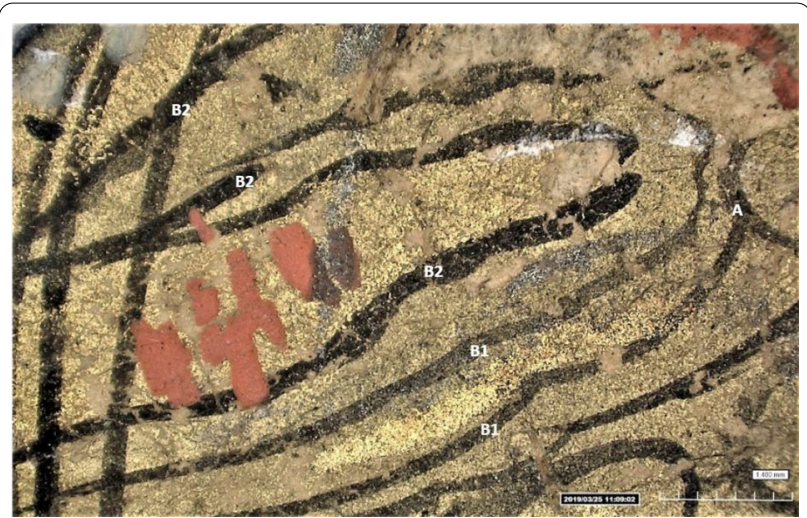

Fig. 10 Detail of the Iranian Youth's dress: B1 Black I, B2 Black II

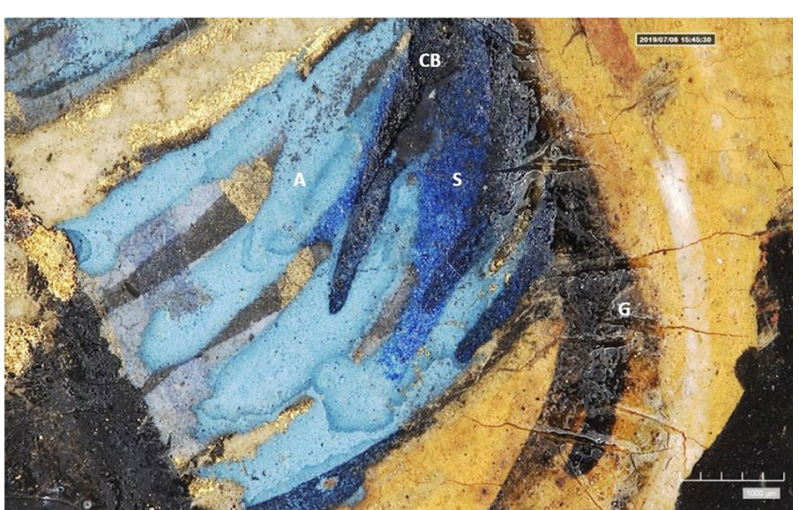

Fig. 11 Micrograph of the sash: A azurite, CB carbon black, S smalt, G glazing. HIROX RH-2000, 40X

pigment (Fig. 8). The presence of two different types of gold was also revealed: the first one of a grayish tone (gold I) and the second of a brighter appearance (gold II). In fact, examination with the Hirox revealed that the dress shows areas of significant damage (abrasions and losses) in the left shoulder and elbow and in the middle and lower part of the garment. It is likely that the blue, purple, red, orange and white dots of the coat as well as the gold II and silver highlights were applied to conceal these damaged areas of the original design and the greyish gold I that has become dull over time (Fig. 9). Gold II was applied on top of gold I in the turban and the cup. In some areas of the coat, greyish and pale blue dots were covered by other dots of a brighter blue (Fig. 9). Two different types of black inks were observed: an 

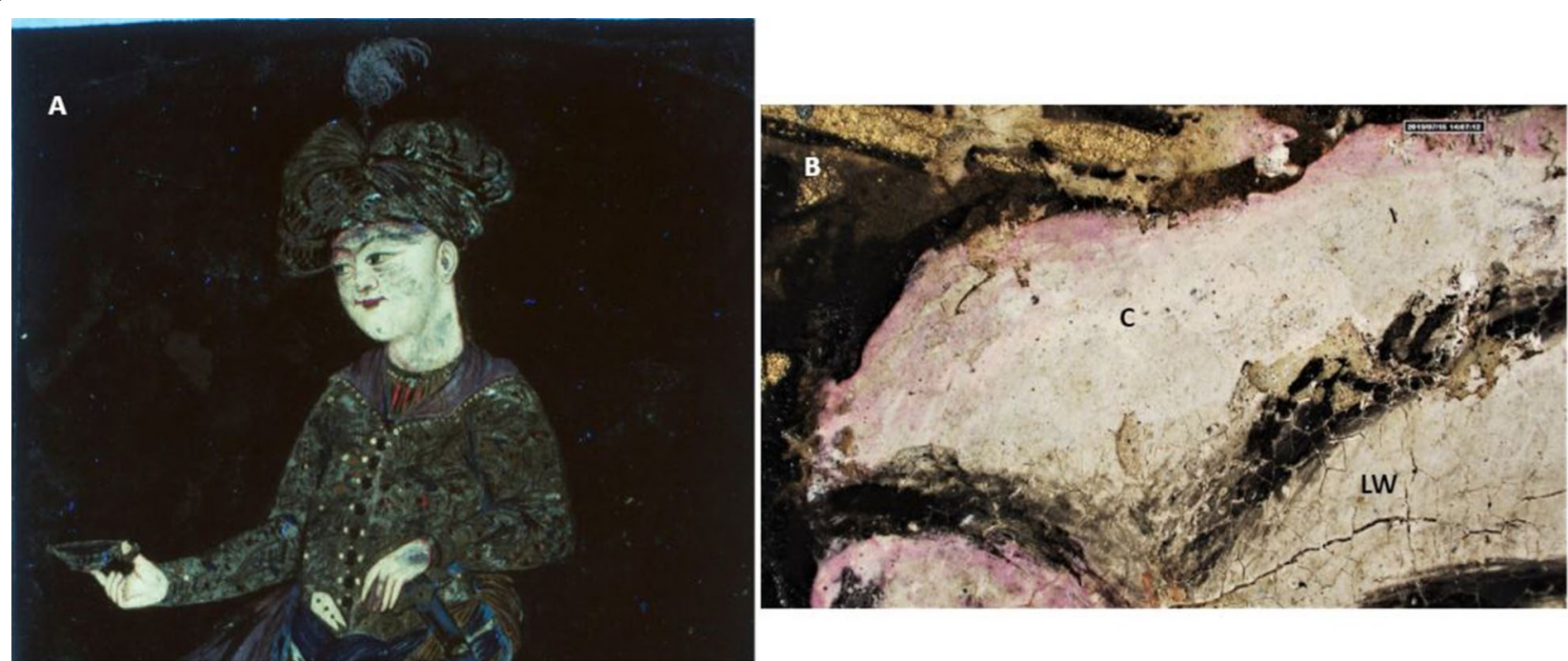

Fig. 12 a Upper half of the Youth in UV light. b Micrograph of the forehead showing the two different types of white paints, C white retouched area above the eyebrow and LW original white paint with craquelures below the eyebrow

underlying dull black line (black I) was covered with a much firmer and darker paint named (black II) in many places (Fig. 10). In some areas painted in black, such as the blade of the sword and the shadows of the blue sash, it was also noted that some kind of glazing had been applied in order to deepen the colours (Fig. 11). The complex stratigraphy and overlapping elements made it difficult to establish the pictorial chronology of the painting without further analytical data.

\section{UV light imaging}

UV light imaging was very useful to provide insight into the changes in the paint layers. Some areas in the face, neck, ear and left hand that showed up dark in UV light and could thus most likely be identified as retouchings, confirming that a white pigment, different from that originally used for the skin, had been used, possibly to conceal flaws or areas of paint loss (Fig. 12a). Examination with the Hirox RH-2000 confirmed the differences in texture of the two white paints: in the dark areas highlighted by UV light, the paint was applied unevenly $(C)$, while, in the light whitish areas, the paint structure was more even, despite showing an overall network of craquelures across the entire surface (LW) (Fig. 12b).

\section{Infrared reflectography}

IRR was used in an attempt to provide additional information on the presence of underdrawing, corrections or modifications. The resulting IR reflectographs show a few lines that indicate the continuity of the pattern of the clouds on the dress and knots of drapery that seemed to be present underneath the existing orange and blue sashes (Fig. 13). However, on the basis of IRR, it was not possible to fully visualize the original composition or potential details hidden beneath the black background, information that could be helpful in identifying the origins of the painting and the artist who created it.

\section{Spectroscopic analysis}

\section{Micro X-Ray fluorescence analysis.}

$\mu$-XRF was used at the beginning of the project as a screening method to provide insight into the different pigments involved in the creation of the work. The method was also used on several other paintings from the album that contain visually similar colours. ${ }^{7}$ The spectra obtained were compared with the spectra of the Iranian Youth and showed similar features in terms of main and trace elements. Lead was found in the face, the hilt of the dagger, the hands and the tights and in a few white dots in the dress and might indicate the presence of lead white. Lead was also detected in the red shoes and suggests the presence of red lead. Arsenic was detected in the orange sash, the cup handle and the undershirt and could be linked to the use of orpiment or realgar. Measurements were also taken in the orange paints present in the sash of Gesina's brother Moses on page 84 (Fig. 3). Traces of calcium, lead, copper and iron were found that could indicate a mix of several pigments, inorganic and/

\footnotetext{
${ }^{7}$ The silver ribbon on page 8 , the silver belt on page 84 , the blue sleigh and the blue skirt on page 45 and 90 respectively, the red skirt on page 157, the red jacket on page 65 and on the red skirt on page 106. The paintings are digitally accessible on https://www.rijksmuseum.nl/nl/collectie/BI-1887-1463 (last visited 16/11/2020).
} 


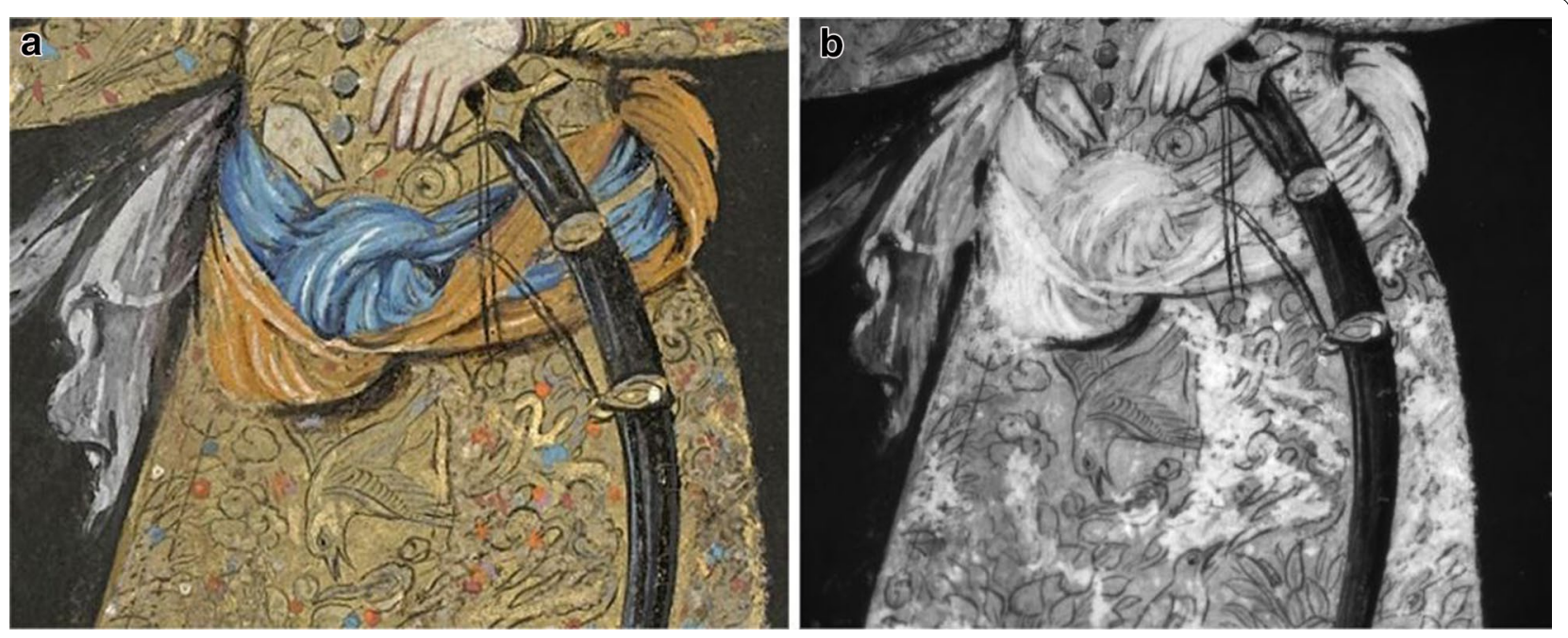

Fig. 13 a Detail of the sashes around the waist with incident light. $\mathbf{b}$ IR reflectrograph of the same detail

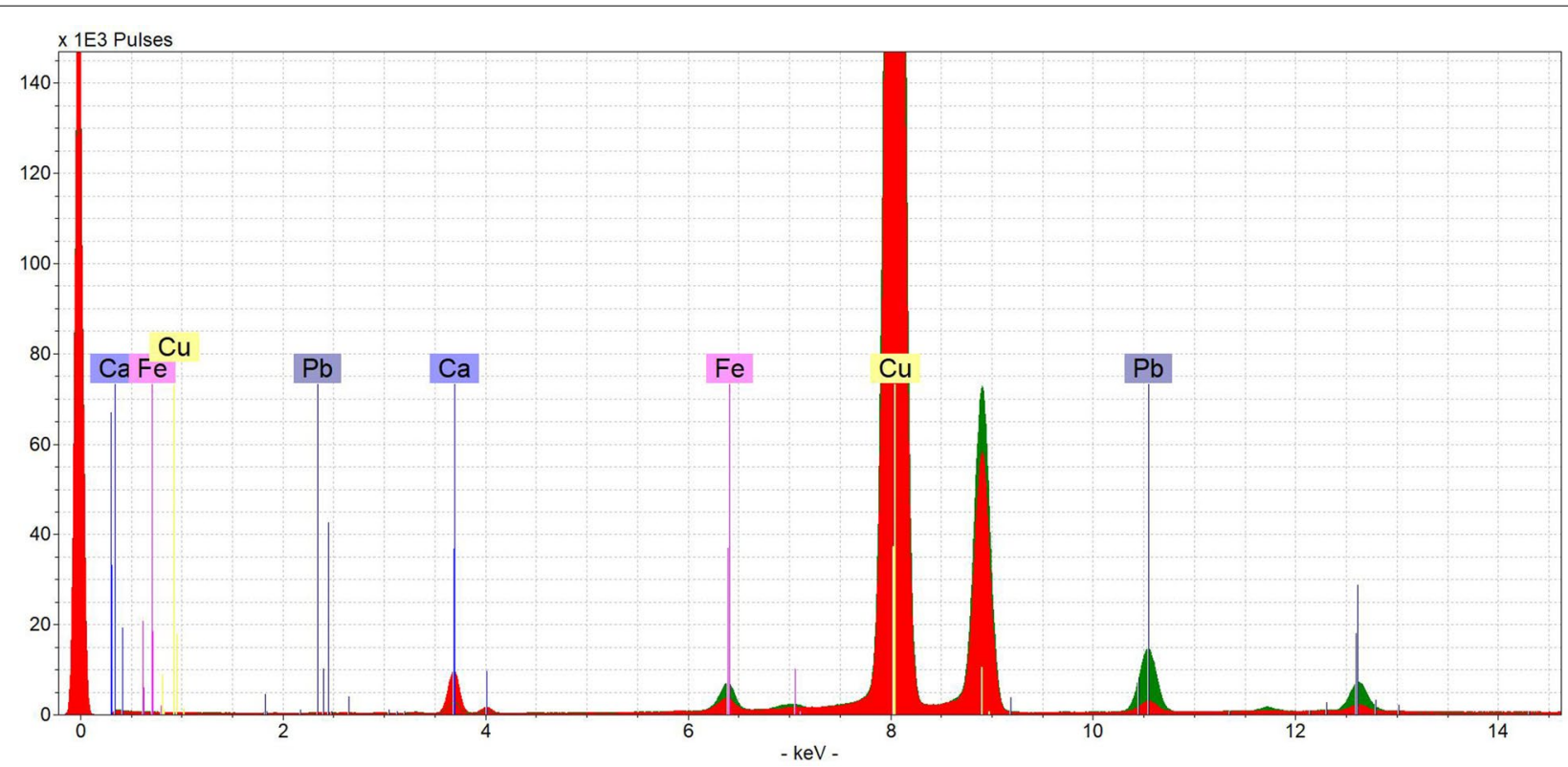

Fig. $14 \mu-X R F$ spectrum of the copper based-blue paint or azurite. In red: measurements taken on page 40; in green: measurements taken on page 45

or organic, to produce the cool orange hue of the sashes in both paintings. A silver-based paint was used for the buttons and as highlights for details of the turban, cup and dress. This silver paint is not found on many other works in the album. Some measurements were taken on two other paintings: the silver paint used for the ribbons in the hair of Gesina's self-portrait on page 8 and in the fringes of Moses' greyish silver sash on page 84 (Fig. 3). All the spectra display similar characteristics: silver as the main element and traces of lead, iron, calcium and chlorine in diverse quantities. ${ }^{8}$ In general, silver peaks are higher in the Iranian Youth's details than in Gesina's hair ribbons and Moses' sash. The silver peak is lowest in the latter painting, suggesting a minor amount of silver paint used in this particular instance. Gold was detected in the dress of the Youth and as highlights in the cup and the

\footnotetext{
${ }^{8}$ Gesina's self-portrait on page 8 of the album https://www.rijksmuseum.nl/ $\mathrm{nl} /$ collectie/BI-1887-1463-8. Moses' portrait on page $84 \mathrm{https} / / /$ www.rijks museum.nl/nl/collectie/BI-1887-1463-84 (last visited 16/11/2020).
} 


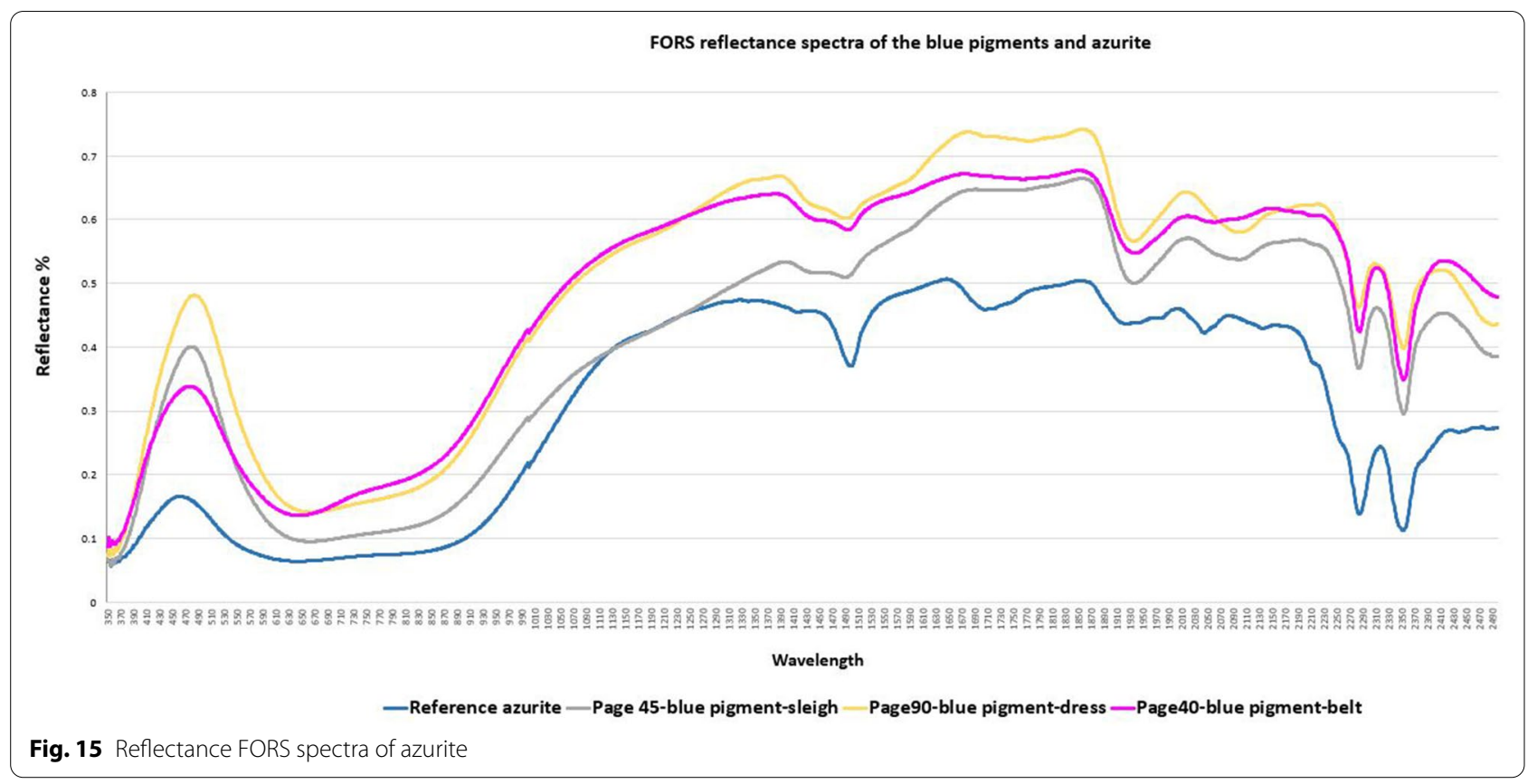

turban. ${ }^{9}$ The blue paint used for one of the sashes seems to be a particularly frequent hue, recurring on many other illustrations in the album, for instance on pages 45 and 90 . For all these areas, $\mu$-XRF spectra show a main peak of copper, with traces of lead, iron and calcium, which could indicate the presence of azurite (Fig. 14).

\section{Fibre optic reflectance spectrometry ${ }^{10}$}

FORS measurements confirmed the presence of azurite in the blue sash. The FORS spectrum showed a reflectance peak at around $450-480 \mathrm{~nm}$, a broad absorption band between 600 and $900 \mathrm{~nm}$, and three characteristic absorption bands in the near infrared region at 1495 , 2285 and $2350 \mathrm{~nm}$, producing a representative spectrum for azurite. For comparison, measurements were also taken from the blue paints present in the sleigh on page 45 and in the blue dress on page $90{ }^{11}$ The spectra obtained from the three paintings all confirmed the presence of azurite (Fig. 15).

\footnotetext{
${ }^{9}$ Gold paint was not considered a primary feature at this point in the research, so no measurements were taken on other works in the scrapbook.

10 The database of Antonino Cosentino served as a reference. Measurements were made from the pigments checker cards, processed with the software provided with the Ocean Optics spectrometer and then compared with the FORS spectra from the painting. This preparatory work was carried out by Simone Gaisbauer BA Conservation student at University of applied sciences Cologne and intern at the Rijksmuseum painting conservation studio in $2018 \mathrm{https} / / / \mathrm{chsopensource.org/product/pigments-check}$ er-tp-msi-calibration-card-included/.

${ }^{11}$ A Sleigh and a Horse https://www.rijksmuseum.nl/nl/collectie/BI-18871463-45 and Portrait of Aletta Pancras https://www.rijksmuseum.nl/nl/colle ctie/BI-1887-1463-90 (last visited 16/11/2020).
}

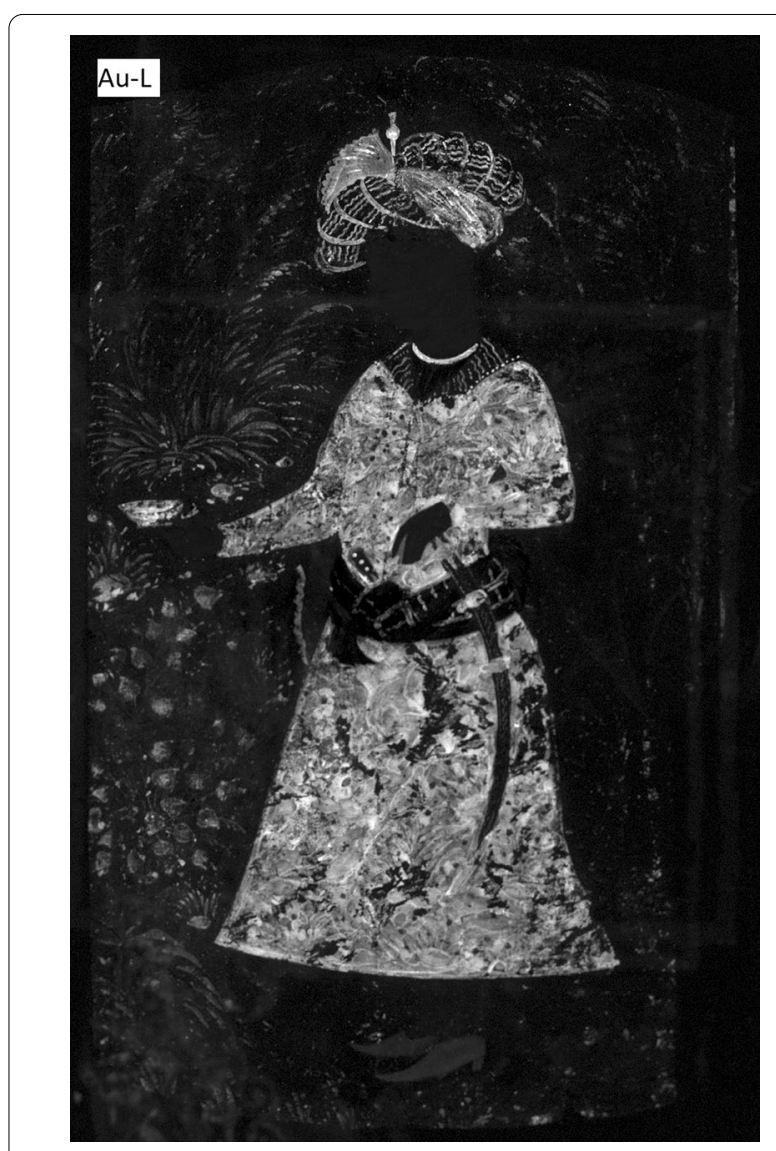

Fig. 16 MA-XRF elemental distribution map for gold (Au-L) 

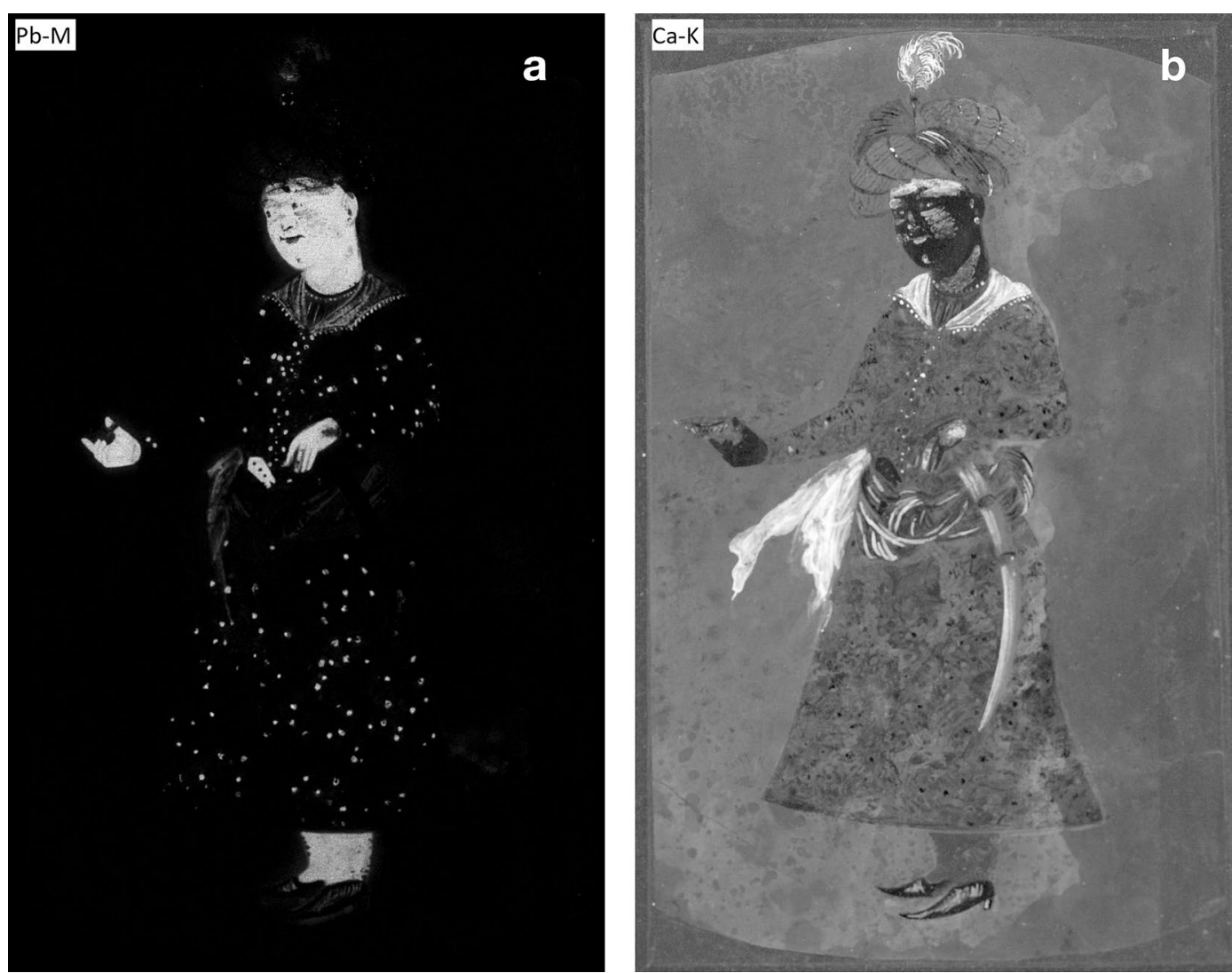

Fig. 17 a MA-XRF elemental distribution map for lead (Pb-M). b MA-XRF elemental distribution map for calcium (Ca-K)

\section{Macro-XRF fluorescence}

The elemental maps obtained by MA-XRF analysis facilitated the visualisation of original designs and later additions. The gold distribution map (Au-L) produced the most striking findings, revealing a decoration of vegetal motifs hidden under the black overpaint (Fig. 16). The design of grassy plants looks very similar to those found in Iranian paintings from the same time period (Fig. 2a, $\mathrm{c}$ and d). Gold is also present in the turban of the Youth. One can observe a different ornament at the top-longer and different in shape than what is visible today-as well as a more detailed contour for the top left part of the turban. Moreover, the top right and lower left parts of the turban contain small quantities of titanium and potassium. Such elements could belong to an earth pigment that has not yet been identified in the painting by other analytical techniques.

Original paint and later retouches could be identified in the regions of the face, hands, hilt and socks of the Youth. These layers appear off-white and are outlined with vermilion (presence of mercury and sulfur). The first layer, which appears highly degraded under the microscope, as shown in Fig. 12b, probably consists of a lead-based pigment (Fig. 17a). The calcium map (Fig. 17b) shows a strong correlation with the damaged areas: the forehead, chin, cheeks, ear, neck and proper left hand, heavily cracked and rich in lacunas, were locally retouched with a calcium-based white pigment (Fig. 12). While many of the areas painted with lead-based white are found in lower layers, therefore presumably belonging to the original miniature, there is also lead present in the collar, on top of a probably original layer of golden stripes. On the basis of the analytical results obtained so far, the chronology of these additions cannot be firmly established and the possibility of multiple campaigns of change should not be ruled out.

The dress shows an equally interesting layer build up, partially unveiled by MA-XRF analysis. The Au-L map confirms the presence of an earlier design in the collar, made out of decorative stripes, now covered by brushstrokes of lead- and calcium-based paint, making the collar appear white.

The observation with the microscope of two different types of gold (the dull and greyish gold I, covered partially by the shiny and warmer gold II) was confirmed by comparing the gold and copper maps (Fig. 9). The 


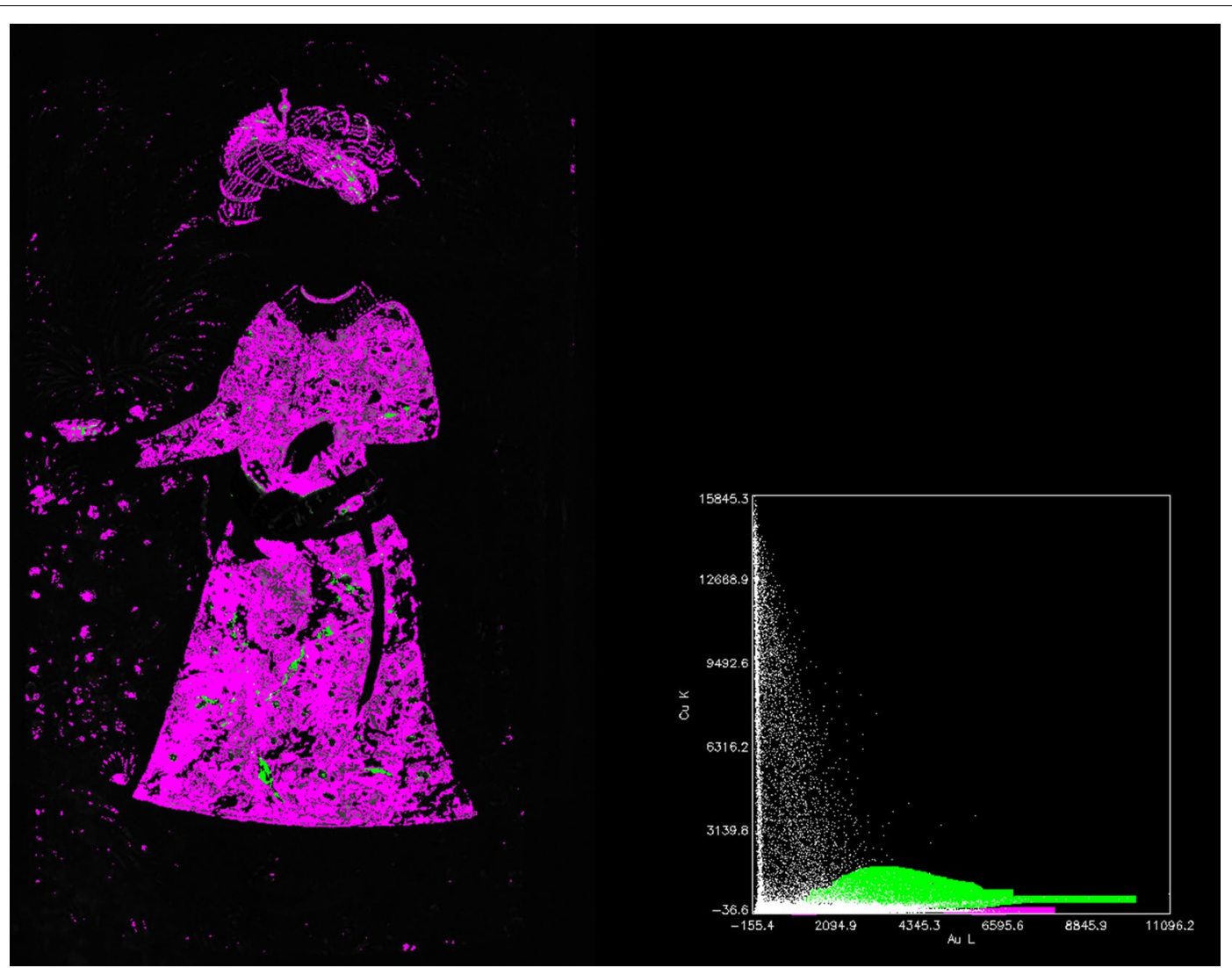

Fig. 18 Correlation plot of the elemental distributions for gold ( $\mathrm{Au}-\mathrm{L}$ ) and copper ( $\mathrm{Cu}-\mathrm{K})$. In pink, the areas of pure gold (gold I). In green, the areas of gold mixed with copper (gold II)

$\mathrm{Au} / \mathrm{Cu}$ correlation plot resulted in the discrimination and mapping of gold I, consisting of pure gold, and later overpaints with gold II, composed of gold and copper, on the dress as well as on the cup held by the Youth (Fig. 18). Based on the examination under the microscope, the silver-based highlights, located on the turban, front buttons and dress, appear to have been applied at the same time as gold II (Fig. 19a). These overpaints might have served the same purpose of hiding damaged patches of gold I from view, especially in the lower half of the dress, as well as brightening up the whole costume. Some highlights, as well as the buttons closing up the upper part of the dress, contain chlorine, possibly indicative of silver chloride $(\mathrm{AgCl})$, a degradation product of silver.

MA-XRF also demonstrated that the white dots running along the collar and on both sides of the silver buttons, with a less bright and partially cracked appearance, are made out of lead and are partially covered by larger and brighter calcium-based dots. Microscopic examination indicates that the application of the calcium-based dots are concurrent with the addition of the silver and gold II highlights (Fig. 8).
Furthermore, the distribution of silicon, aluminium and potassium as well as copper (Fig. 19b) shed some additional light onto the various hands involved in this area of the painting. Close examination led to the discrimination between greyish blue (blue I) and brighter blue (blue II) dots. FORS identified the blue II, partially covering blue I, as azurite. The overlap of $\mathrm{Si}, \mathrm{Al}$ and $\mathrm{K}$ maps in the locations of the blue dots indicates that the first series of blue I dots, spread over the lower part of the dress and on the proper left shoulder, might consist of lazurite (natural ultramarine or lapis lazuli). The $\mathrm{Cu}$ map shows the locations of the blue II dots, confirming the presence of azurite. Moreover, in the K map, some of the $\mathrm{Cu}$-based dots appear as black pixels, indicating that the copper signal blocks the potassium signal. This validates the observation made under the microscope: blue I (lapis lazuli) dots were applied before blue II dots (azurite). It seems that the blue dots painted on the upper half of the dress (except from the one on the proper left shoulder) were not part of the first design, as no lapis lazuli elements were detected near or around the dots.

Similarly, the small purple-red dots were identified as vermilion by the presence of mercury and sulfur. These 

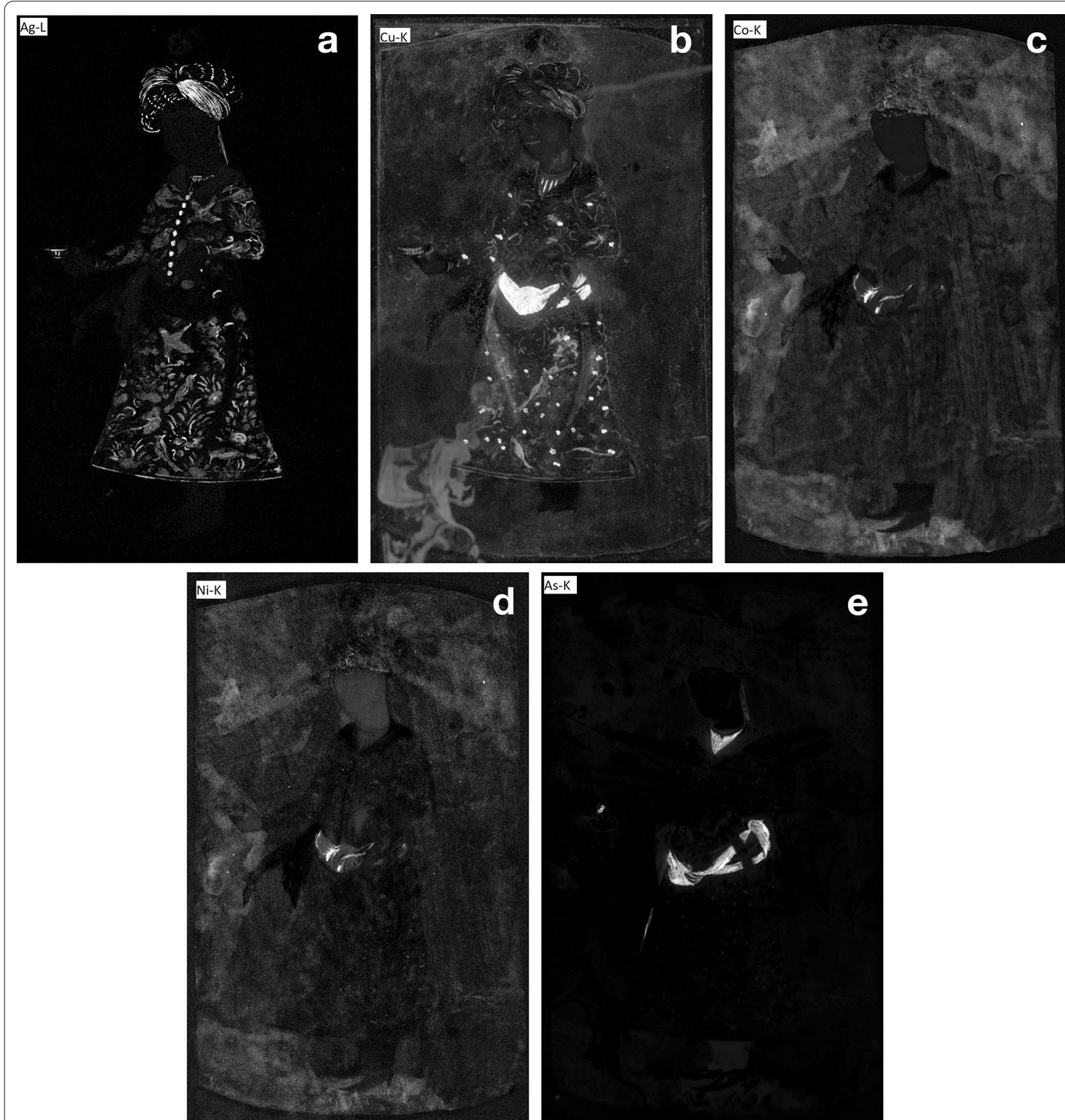

Fig. 19 MA-XRF elemental distribution maps for a silver ( $\mathrm{Ag}-\mathrm{L})$, b copper ( $\mathrm{Cu}-\mathrm{K})$. The design on the lower left corner comes from the contribution of the drawing of a sleigh present a few pages behind the miniature (page 44), c cobalt (Co-K), d nickel (Ni-K), e arsenic (As-K)

small touches of paint cover some of the paint losses (especially in the lower half of the dress), which might indicate that they were applied at a later stage to conceal damage. Interestingly, these vermilion dots were then partially covered with gold II (mixture of gold and copper) and larger orange dots, characterised as red lead. This observation may strengthen the hypothesis that several interventions were done on the miniature at a later stage. The lead-rich dots that appear white in visible light were identified as later lead-white additions. The comparison of mercury, sulphur and lead ( $\mathrm{Pb}-\mathrm{M})$ maps reveals that many red lead dots are new and do not cover any former vermilion dot. 


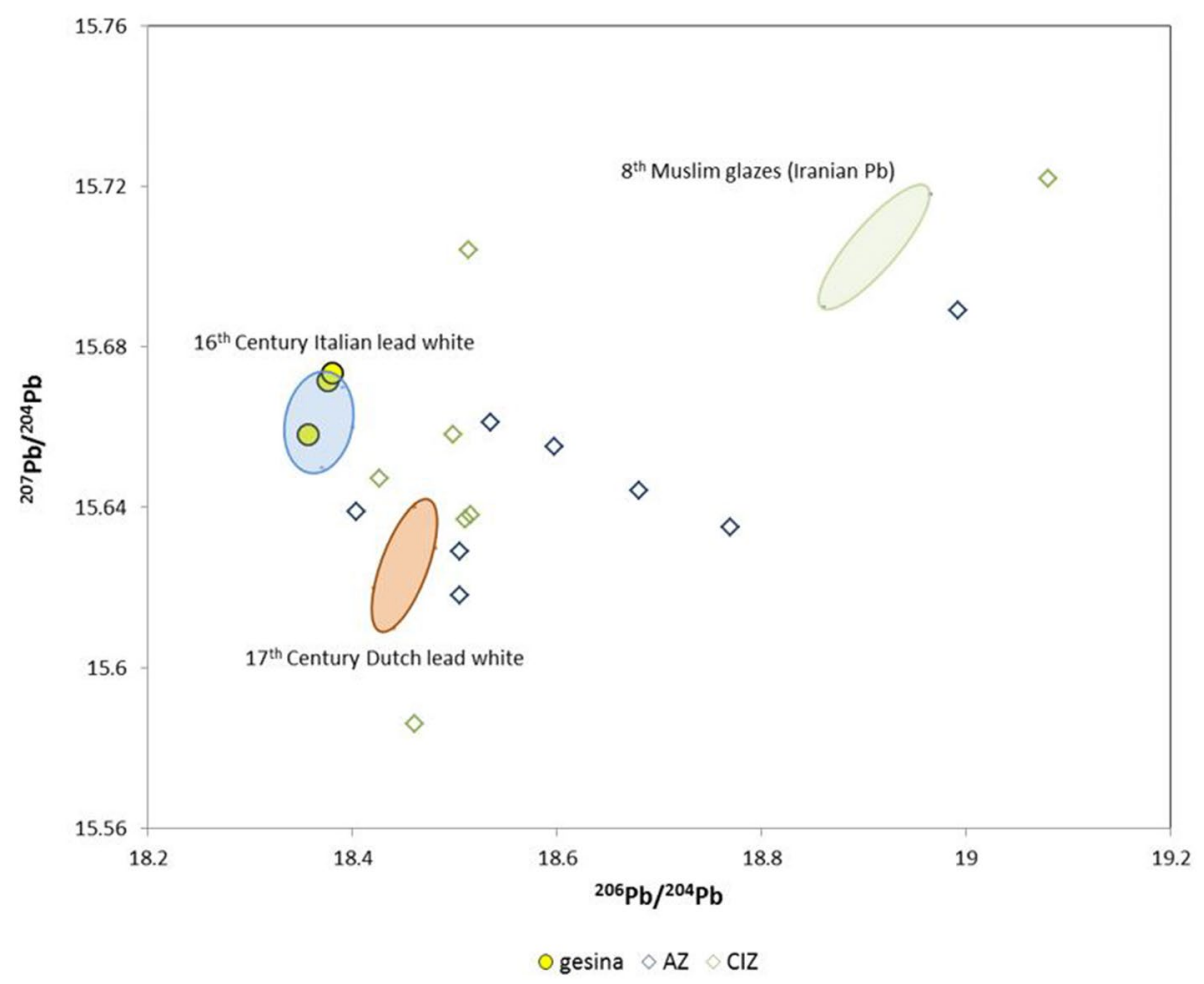

Fig. $20{ }^{206} \mathrm{~Pb} / 204 \mathrm{~Pb}$ vs. ${ }^{207} \mathrm{~Pb} / 204 \mathrm{~Pb}$ ratios diagram. The figure reports data for 16 th Century Italian and 17th Century Dutch lead white as blue and orange fields [13, 14]. The green [DG1] [IPd2] field shows the values of Iranian lead in ceramic glazes identified in the study from Wolf et al. [17]. The diamonds are values for Iranian galena from the Alborz (AZ) and the Central Iran Zone (CIZ) present in Hassan Mirnejad et al. [18]. The samples from the illustration are the yellow circles. The analytical uncertainty, as the 2SD usually reported as a cross, is smaller than the marker and therefore is not visible in the graph

The lead map also proved that more invasive changes were implemented on the original miniature (Fig. 17a). First, it unveiled a detail of the initial design that is barely visible today: a floating sash on the proper right hand side of the waist, covering part of the dress with a different movement than the present white calcium-based floating veil on black background. Second, the distribution map shows that the socks were originally wider and probably similar to other Iranian paintings mentioned earlier (Fig. 2a, c, d).

At the centre of the miniature, the sashes around the waist and scabbard were subjected to changes too. The gold $(\mathrm{Au}-\mathrm{L})$ map revealed details of an earlier and thinner belt, hidden under the blue sash, decorated with golden stripes (Fig. 16). The blue sash is made out of copper for the medium colour, identified as azurite with FORS, while the white highlights are rich in calcium. The darker areas contain nickel, arsenic and cobalt, probably from smalt, a blue pigment consisting of ground cobalt containing potassium glass (Fig. 19c-e and Fe-K). The same pigment was used to cover large parts of the now dark background, which suggests that the background covering the miniature's original background had a different hue after application than it has today. MA-XRF analysis also revealed the chemical composition of the orange sash. The main body of the belt is rich in arsenic and sulphur (Fig. 19e, S-K), while the white highlights are calcium-based, the red areas consist of mercury and the shadows contain manganese and iron. Finally, based on the gold map, it is possible to ascertain that the scabbard hanging from the belt was originally thinner, with a decoration pattern of curved stripes.

\section{Lead isotope analysis}

Lead isotope analysis was performed in an attempt to trace the provenance of the lead white used in the painting and thereby find out more about its geographical origins-Iran or the Netherlands. Lead isotopes of lead white have been successfully used in the last decades to determine the provenance of lead used in European artworks. In principle, the lead present in lead white retains the isotopic composition of the lead present insource 
deposits, allowing provenance of the pigment by direct comparison with isotopic databases ${ }^{12}[19,20]$. Differences in lead isotope ratios have been used to distinguish between different groups of art works [13-16]. The theory behind the use of lead isotope analysis in paintings is well defined and can be found in detail in many publications $[12,16]$.

Samples B.1887.1463-40-2 and B.1887.1463-40-4 are within analytical error (therefore their isotopic composition can be considered identical) which suggests a common source for the lead used. Sample B.1887.1463-40-1, taken from the white hilt of the dagger, shows a significant difference in isotopic composition compared to the aforementioned samples. The reason for the different isotopic composition of sample B.1887.1463-40-1 is not clear. It is possibly related to the sampling process during which the lead white sample may have been contaminated by lead from a different pigment, altering the final lead isotopes composition. ${ }^{13}$

Figure 20, featuring the ${ }^{206} \mathrm{~Pb} /{ }^{204} \mathrm{~Pb}$ versus ${ }^{207} \mathrm{~Pb} /{ }^{204} \mathrm{~Pb}$ ratios scatter plots, shows the results of the lead white present in the painting plotted against the data present in the existing literature. In the figure, the blue and orange circles indicate data for sixteenth century Italian and seventeenth century Dutch lead whites collected by Fabian and Fortunato $[13,14]$. The green circle shows the values of Iranian lead white identified in the study from Wolf et al. [17] The rhombus are the values for Iranian galena from the Alborz (AZ) and the Central Iran Zone (CIZ) present in the research by Mirnejad et al. [18]. The samples from Gesina's album are represented by yellow circles. The most important conclusion of the lead isotope analysis is that the isotopic composition of the three samples from Gesina's scrapbook do not match the values of Dutch seventeenth century paintings. This indicates that the original miniature was painted using pigments not made or used in the Netherlands. The lead isotope analysis, however, cannot confirm an Iranian provenance of the lead white, since the values found in the three samples are distinct from any Iranian lead isotopes found in literature $[17,18,21-25]$. However, given the scarcity of available information about the lead isotopes of lead white used in Iran in this period, a potential Iranian provenance of the materials used cannot be excluded on the basis of these data. The data clearly show that the values for lead isotope ratios found in the miniature match the values of sampled sixteenth century Italian paintings

\footnotetext{
${ }^{12}$ Examples are the OXALID (http://oxalid.arch.ox.ac.uk/The\%20Database/ TheDatabase.htm) or the AAcP Alpine Archaeocopper Project http://geo. geoscienze.unipd.it/aacp/welcome.html) databases.

13 This difference has been already observed, and with the same magnitude, in a study on Dutch paintings, with a distribution similar to what was found for the samples from de Gelder's painting [12].
}

[13, 14, 16]. In particular, the values found for samples B.1887.1463-40-2 and B.1887.1463-40-4 fall within the region of sixteenth century Venetian lead white cones of raw pigment $[16,26]$ and may indicate the use of Venetian lead white. However further analysis of Iranian lead white produced in this same period is needed in order to correctly assign the provenance of the pigment. ${ }^{14}$

\section{Interpretation and discussion: geographical markers}

Further questions related to the lead white

The results on lead white isotopes showed a strong correlation with sixteenth-century Venetian lead white. The current state of knowledge points towards two likely scenarios: either we are dealing with a Venetian pigment traded to and used in Iran or with an Iranian pigment coming from a source with a comparable isotopic footprint that has not yet been analysed.

The first hypothesis, which assumes that the miniature was painted in Iran with Venetian lead white, is based on the composition of the lead white used in Italian paintings and the isotopic ratio of lead found in the Venetian lead white cones of a ship that sank while transporting goods to Constantinople in 1583 [13-16]. Until the ascension to the Iranian throne of Shah Abbas the Great (1587-1629), who intensified diplomatic relations with Europe, direct contact between the West and Iran was sparse and economic, cultural and artistic exchanges between Christians and Muslims took place in the Levant, namely at ports such as Cairo, Damascus, Aleppo and Constantinople. The use of Venetian lead white in Iranian objects is based on the assumption that the Venice republic traded goods, including pigments, with the Middle East. Already, at the end of the Middle Ages, Venetian traders occasionally arrived in Iran. They travelled via the old land trade routes, but also via the Black Sea. On the East coast of the latter, Venetian merchants settled and even opened a trading post in Tabriz. At the beginning of the seventeenth century, historical records show that Venetians arrived in Isfahan itself. One of the traders is even documented as trading in paintings. Between the sixteenth and eighteenth centuries, trade with the Middle East was compromised and often interrupted altogether due to the political struggles between the so-called Gunpowder Empires, involving the Ottomans, Safavids and Mughals, in Turkey, Iran and India respectively. Venetian trade with Iran was however not very extensive and overshadowed first by the Mamluk and later by the Ottoman merchants established in the Levant. Furthermore, there

\footnotetext{
${ }^{14}$ The authors do not exclude possible existing literature published in the Farsi language, which they could not find despite several attempts to communicate with Iranian scientists.
} 
is no direct indication or source proving that the Venetians exported lead to Iran. While lead white cones were found in the aforementioned Venetian ship, there is no proof that these cones were intended for the Iranian market [26].

The second hypothesis, involving the use of a pigment coming from an uncharacterized Iranian source, is based on the historical literature stating that lead and lead white were abundantly present and used in Iran in the sixteenth and seventeenth centuries [27-33]. ${ }^{15}$ However in order to confirm this hypothesis, analysis on Iranian lead deposits and lead white used in this period are needed.

It is unclear to what extent and for which purposes lead was mined in Iran. It seems that lead was mined only intermittently because of an imperfect infrastructure, lack of adequate financial and labour resources and inefficient mining and processing techniques. In contrast, two English merchants, visiting Iran in 1618, explicitly stated that it made no sense to export lead to Iran because the country had more than enough lead mines and lead was therefore just as cheap as in England ${ }^{16}$ [34].

From a technical point of view, lead white, called sefidāb or isfidāj in Persian, was a pigment widely used in Iranian miniature painting and was produced from the early ages. One of the oldest treatises, Bayan al-sana'at, written by Hubaish Ebrahim Tiflisi in the thirteenth century, mentions the use and the recipe of lead white in art and cosmetics [27]. The pigment, a lead carbonate $\left(2 \mathrm{PbCO}_{3} \times \mathrm{Pb}(\mathrm{OH})_{2}\right)$, was artificially produced by exposing lead scraps to acetic acid vapours from vinegar under the action of heat. During the Safavid era, a few treatises report the recipes. For example, Sadeq Beyg Afshar (1533-1608), painter and chief librarian of Shāh Abbās $\mathrm{I}$, in his Qanun al-sovar (canons of painting), wrote a modification of the aforementioned method that involves heating lead and then treating it with vinegar. However, none of these historical sources, written in a poetic manner, mentions the origins of the lead and whether it was sourced locally or not. As highlighted in recent analytical studies, lead white was most widely used alone or in mixtures [28-33]. Interestingly, calcite was identified on rare occasions as a stand-alone pigment. In a few studies,

\footnotetext{
${ }^{15}$ According to Iranica Online entry:"Most of Iran's lead and zinc output comes from eight mines: Āhangarān, Angurān, Emārat, Irānkuh (Isfahan), Kušk (Yazd), Naklak, and Ravanj. Although the deposits are widely spread, except for the Angurān mine (southwest of Zanjān), the major mines are near Yazd and Isfahan" https://www.iranicaonline.org/articles/mining-in-iran-ii (last visited 16/11/2020)

${ }^{16}$ R.W. Ferrier (1976) reports the saying of Edward Pettus and Thomas barker [31]: "Leade (161) allmost as cheape heere as in England whereof ys mynes in sundrye places from whence the whole Persian territoryes is sufficiently supplyed being used onely to make shott yet we shall propound unto the kinge the takeing of a quantetye yearely at the porte from whence he maye transporte it to the Arabian shoare in fysher boates of his owne countrye where it will yeilde him great gaynes".
}

it was found as impurities in malachite or lapis-lazuli and in a ground layer and in a nineteenth century paint box [30-32]. All of these sources contribute to a fairly good understanding of lead white compositions in Iranian paintings. ${ }^{17}$

Despite all this significant information, it is, for the moment, not possible to confirm the Iranian provenance of the lead white present in the miniature. Further analyses on similar objects, preferably from the seventeenth century, would be necessary to identify the lead composition and isotopes in the region during this period. For now, it is only possible to conclude that the lead white used in the miniature was not Dutch.

\section{Blue pigments: lazurite, azurite, and smalt}

The MA-XRF maps and FORS spectra revealed the presence of three blue pigments: lazurite, azurite and smalt. Is it possible to use these pigments as geographical markers for the miniature ${ }^{18}$ ? Lazurite, a blue pigment extracted from the lapis lazuli gemstone, has been widely used in Iranian paintings since ancient times. It has been reported in several scientific studies to be one of the two main sources of blue, together with indigo [27, 28, 33]. Lapis lazuli was mined in the Badakhshan region of Afghanistan, more precisely in Sar-e Sang, $2500 \mathrm{~km}$ away from Isfahan. However, lapis lazuli stones were exported to Europe since the Middle Ages, crushed into powder to produce ultramarine. Lazurite cannot therefore be considered as a geographic marker for a specific region, as it was used in both cultures. Azurite cannot be considered a unique geographical marker either, since although it is much more abundantly used in Western art, it has also been found, albeit on rare occasions, in Iranian paintings. ${ }^{19}$

\footnotetext{
${ }^{17}$ Mandana Barkeshli, through her analytical research projects, has translated numerous treatises and recipes, analyzed various materials and therefore has widely contributed to the development of knowledge in the field.

18 The various sources of blue colours in manuscripts and album paintings were highlighted in many treatises translated and studied by Mandana Barkeshli and are as follows: turnsole, indigo, lapis lazuli, azurite, mavi (mixture of indigo and safflower) and artificial ultramarine (mixture of indigo and lead white).

19 Knipe P. et al. revealed that azurite was used for specific reasons in five artworks over fifty folios analysed: either as natural mixed ore with malachite, or as a local choice specific to an artist or workshop, or as later alterations and retouching. Azurite was also identified in the Demotte Shahnama, made in the fourteenth century [28].
} 
As for smalt, the pigment was made from crushed blue glass tinted blue with a certain amount of cobalt. In Iran, cobalt blue, mined in the Qamsar deposit, near Kashan, in central Iran, was one of the earliest and largest known cobalt ores in the region. ${ }^{20}$ The mineral was exported from early on, to Mesopotamia, Egypt and China. More information about the mineral can be found in sources on ceramics, glass and archaeological materials. Cobalt was used to colour in blue glass and ceramic glaze and several treatises report the making processes, among them Abu al-Qasim Kashani in 1301 [35, 36]. Kashani explicitly mentions the cobalt from Kashan mine and from Farangistan (that is to say the country of the Franks or the Persian name for Europe) ${ }^{21}$ It is therefore certainly, at the beginning of the fourteenth century, the oldest reference on an European importation of smalt, to be used to colour ceramics. [35, 37]. Because its deep colour was close to that of lapis lazuli, it was also used in wall paintings, as a cheap substitute to the semi-precious stone [38]. ${ }^{22}$ That is the reason why cobalt blue was called lajvard which, in Persian, refers to the village of Laj in Badakhshan, Afghanistan, well known as a source of lapis lazuli from ancient times. If the Kashan ore is not a source of lapis lazuli, it is likely that this attribution was due to the lazuli colour of the cobalt blue pigment procured from this deposit [36].

In Europe, cobalt ores were discovered in Saxony in the mid-fifteenth century and fully exploited around 1520. The mineral was processed to produce zaffre, the material used to colour glass, ceramics, and produce smalt. Then, in the sixteenth century, the pigment spread throughout Europe and in particular among Venetian glassmakers. The Netherlands became an important production centre, using cobalt ores imported from Germany, and exporting smalt throughout Europe [39]. Dutch artisans made great use of it for the manufacture of blue tiles in Delft and Dutch painters added smalt to their palette. Painters like Rembrandt mixed blue smalt with lakes, earths and black pigments to change the properties of paint layers (texture, drying, translucency,

\footnotetext{
${ }^{20}$ There were also important deposits in Bache Barg in Azerbaijan and in the small towns of Meskani and Talmesi (near Anarak, 200 km from Kashan) and, lesser deposits at Emamzada Da'ud near Tehran and Berenjiki in Balochistan $[35,37]$.

${ }^{21}$ Kashani says that Farangistan cobalt blue is ash-coloured and soft.

${ }^{22}$ The analysis carried out with Raman and XRF on the wall paintings of the Masjid-i Jame of Abarqu, central Iran, showed that the blue pigment was smalt mixed with natural ultramarine blue respectively applied on a white substrate composed of white huntite. Moreover, the blue smalt was identified to be used on the white huntite and under the paint layer in order to delineate the design of the wall paintings and to act as a rough sketch for the subsequent use of the other pigments.
}

colour deepening) [40]. Nonetheless, there is no existing VOC (Dutch East India Company) document or correspondence from the seventeenth century that could indicate the exportation of smalt from the Netherlands to Iran. ${ }^{23}$ The VOC (founded in 1602) was allowed to open several trading posts in Iran, including in Isfahan, Shiraz and Bandar-Abbas, after successful negotiations with the Shah in 1623. However, rather than artists' pigments, it is known that the most imported goods, supplied by the VOC, were pepper, spices and sugar, all produced in the Dutch colonies [41]. ${ }^{24}$ In return, silk was the main luxury product exported from Iran to the Low Countries. Dutch travellers venturing into Iran make no reference in their travel reports to any commerce or use of smalt for manuscripts. Cornelis de Bruyijn, who visited the workshop of an Isfahani painter in the first decade of the eighteenth century, mentioned the use of lapis lazuli. ${ }^{25}$ The first explicit reference to cobalt mining and production was made by an Austrian traveller and dates from much later, in the nineteenth century [36]. ${ }^{26}$ Finally, the first Dutch account to mention cobalt from Kashan was written by Johann Louis Schlimmer in 1874 [36]. ${ }^{27}$

Smalt has also been identified in the neighbouring countries of Armenia and India, albeit in rare occurrences, respectively in a fifteenth century illuminated bible made around the Lake Van [42] and seventeenth century miniature paintings from Rajasthan [43, 44]. For this latter example, the cobalt used could have come from the Khetri mines in northern Rajasthan, the closest cobalt deposit to the region identified in mineralogical literature. [37, 45]. European manufactured pigments such as Prussian blue and smalt were indeed imported and used in paintings but only in eighteenth and nineteenth centuries works and not earlier ones $[28,46] .{ }^{28}$ At that time,

\footnotetext{
${ }^{23}$ Information given by Willem Floor during an informal conversation on 07 June 2021.

${ }^{24}$ Willem Floor gives the whole list of VOC exports: spices, textiles, tin, camphor, Japanese copper, powdered and lump sugar, zinc, indigo, sappan wood, china root (Smilax china) gum lac, benzoin, iron, steel, and sandalwood.

25 In page 173 of his Reizen over Moskovië, door Persië en Indië, he wrote that "ultramarin" or "lazour" was the most beautiful blue colour. Further, he says that they make this colour themselves or they get it from the Armenian painters. Because they have the "lazuursteen" [lazour stone] or "Lapis Lasuli" in their own country, from where we get it.

${ }^{26}$ Jacob Eduard Polak was an Austrian physician who travelled through Iran in 1865 and reports the high quality of cobalt in his essay Persien: Das Land und seine Bewohner; Ethnographische Schilderungen.

${ }^{27}$ In his Terminologie Medico-Pharmaceutique et Anthropologique Française-Persane, pages 142 and 339.

${ }^{28}$ Knipe et al. found Prussian blue in a nineteenth century painting from the Qajar era. Newman reports smalt in two eighteenth century Persian illuminated manuscripts.
} 
trade with Europe and Venice was more fully developed than during the seventeenth century.

A recent geological and mineralogical study provides characteristics of the Kashan ore and analytical data of historical ceramics [47]. The results show that cobaltite (CoAsS $)$ and erythrite $\left(\mathrm{Co}_{3}\left(\mathrm{AsO}_{4}\right)_{2} \cdot 8 \mathrm{H}_{2} \mathrm{O}\right)$ are the two main cobalt-bearing minerals in the ore, both of them containing arsenic, and associated with magnetite, pyrite and chalcopyrite. Therefore, pigments made from Kashan minerals should be characterized by high values of arsenic and iron, but not by nickel, zinc and copper. In other words, a cobalt pigment containing significant traces of zinc, copper or nickel cannot originate from Kashan.

In Gesina's Iranian Youth, smalt was identified in the blue sash and in the black background. In a detail of the sash, one can clearly see the different texture and colour of the two blue pigments present here, azurite and smalt. The latter shows a glassy structure and a deeper blue hue (Fig. 11). As highlighted by MA-XRF maps, the smalt areas of the painting contain cobalt, nickel, arsenic, potassium, iron and silicon. The presence of nickel rules out a provenance from the Kashan deposit, but it is impossible to derive any other geographical information from the specific composition of the smalt used.

\section{Interpretation and discussion: art historical considerations}

As summarized in Table 1, extensive visual examination and MA-XRF mapping showed that the artwork may have undergone two separate interventions over time; as a result some parts of the work were heavily overpainted. However, most of the pigments used could not be used as reliable geographic or temporal markers. The analysis of the lead isotopes could not determine with certainty a specific geographical provenance other than the fact that this pigment did not come from the Netherlands.

Can the study of style and history provide the missing pieces of this puzzle in the absence of conclusive analytical results?

What can be said about the original painter? The art historical study has shown that the Iranian Youth is connected iconographically and stylistically to the Safavid compositions of the environment of the painter Riza Abbasi and his followers. Although identification of the original composition and detailed stylistic comparison were compromised by the overpaintings and alterations, the characteristic pose, the landscape, the clothing and the specific pattern of the dress indicate that the original painter likely belonged to the seventeenth century Isfahan School.

The fact that this miniature ended up in the Ter Borch scrapbook is noteworthy, as there was not much interest in nor appreciation of Iranian miniature painting in seventeenth-century Europe. Several Western travellers in Iran expressed extreme disdain for it. The Dutch traveller-artist, Cornelis de Bruijn, called the Iranian miniatures "heavy, flat and void of art" [48]. Examples of Iranian miniatures were very scarce in Europe. The VOC archives make no mention of any trade in Iranian painting, and the inventories of the many art and curiosities collections in the Republic barely include references to Iranian miniatures, in contrast with Indian miniatures that were actively collected at the same time by the Dutch.

Yet it was recently shown that a series of Iranian miniatures did reach the Netherlands as early as the beginning of the seventeenth century [2]. They are most likely paintings by the famous court painter Riza Abbasi or an artist from his immediate circle. The miniatures were acquired in Isfahan by Nicolaas Hem, a Dutch merchant who was a member of the first VOC trade mission to the shah's court led by Hubert Visnich in 1623. It is likely that Jan van Hasselt, who worked as a court painter at the Royal Library at Isfahan and played an important role in the negotiations between the VOC and the shah, was involved in Hem's acquisition of the miniatures [49]. The originals have unfortunately been lost, but we know their composition from a series of eight small woodcuts made after these Iranian miniatures by Cornelis Claesszoon Duysend, which appeared in 1633 in Johannes de Laet's Persia seu Regni Persici Status. One of the Iranian men depicted in the woodcuts shows a remarkable resemblance in pose and dress to the Iranian Youth from Gesina ter Borch's sketchbook (Fig. 21).

Despite the fact that not many Persian miniatures were collected in the Dutch Republic, this shows that Dutch travellers did occasionally bring examples of Iranian painting to the Netherlands. If Hem imported works by Riza Abbasi or an artist close to him into the Netherlands, then another miniature from the vicinity of this Isfahan master may have reached the Republic later via a similar route.

What can be concluded about the artist who retouched the painting? Some of the overpaints are decidedly Western in style. The colourful sashes, for instance, are rendered in a much more pictorial and three-dimensional way than other parts of the miniature. Iranian artists were already receptive to Western painting from the sixteenth century onwards [50]. Knowledge of Western art reached the country mainly through imported prints. Safavid painters depicted European travellers, nudes and even Christian and mythological scenes. In the second half of the seventeenth century, leading painters such as Muhammad Zaman and Ali Quli Jabadar popularised the firangi-sazi, meaning made "in the European manner". They adopted Western painting techniques, such as 


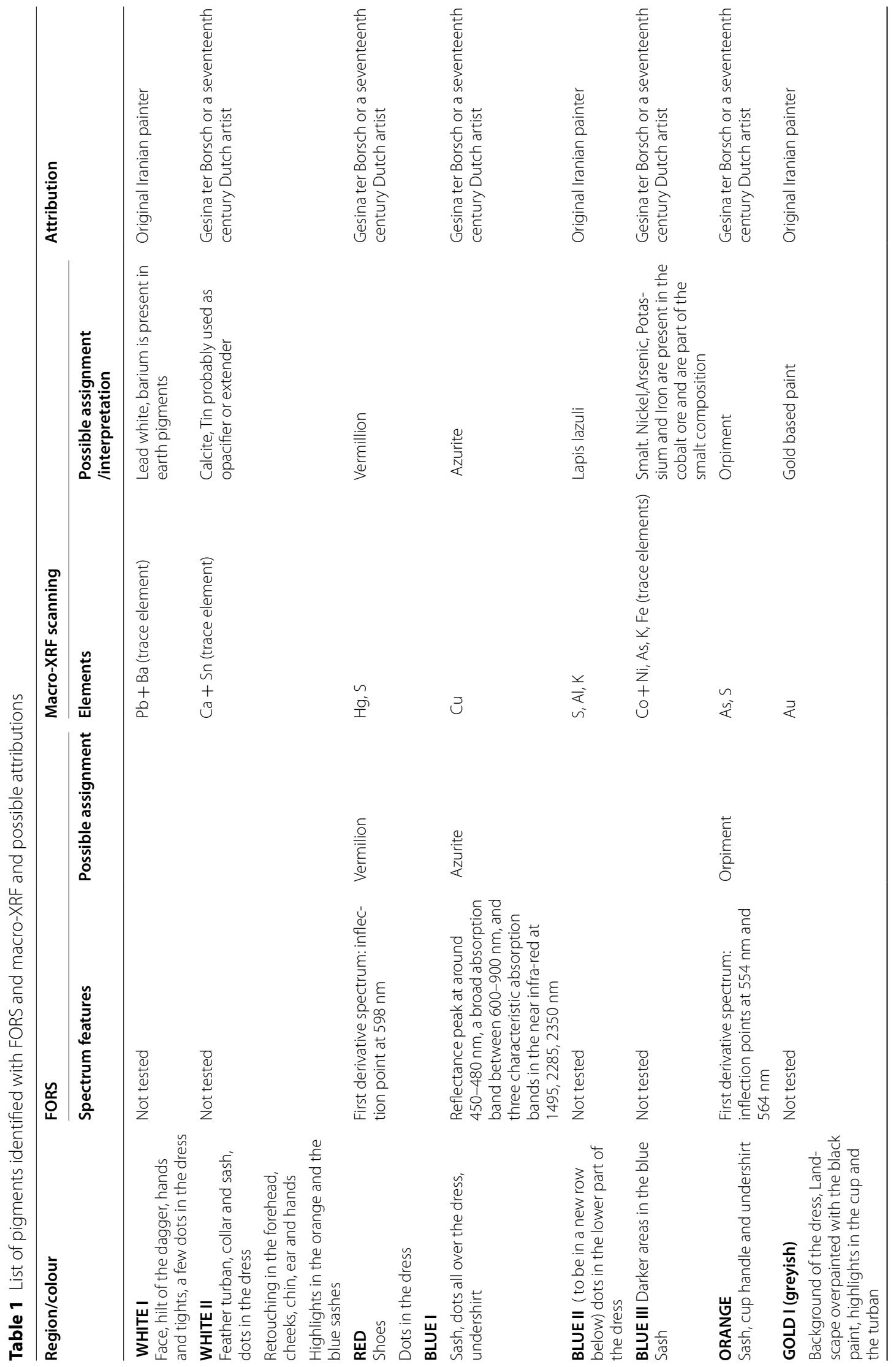




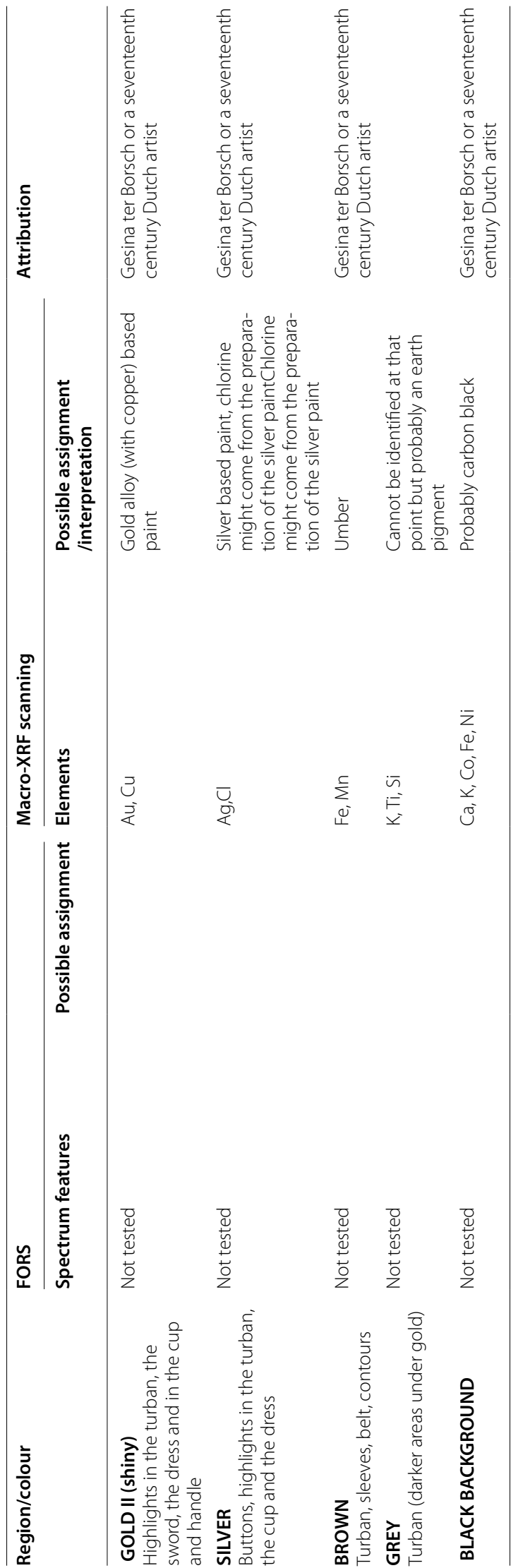




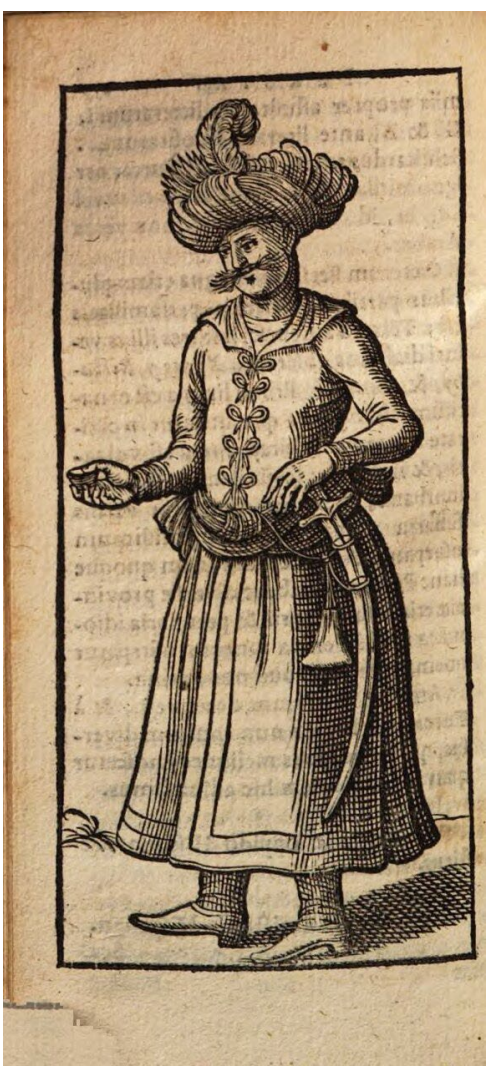

Fig. 21 Woodcut by Cornelis Claeszoon Duysend, from Johannes de Laet, Fig. 24 p. 148, Persia seu Regni Persici Status, Leiden 1633. Regensburg, Staatliche Bibliothek, sign. 999/ Hist.pol.1788. Photograph: Bayerische Staatsbibliothek, Munich

atmospheric and central perspective, shading and chiaroscuro. In the seventeenth century various European artists travelled to Iran in the hope of finding work there, some even becoming court painters for the Shah's royal atelier, such as Jan van Hasselt $[51,52]$.

Yet while the three-dimensional effects in Gesina's miniature could potentially be the work of artists based in Iran, it is not likely that they would have retouched the miniature in this peculiar, hybrid form, adding elements-such as the dark background-that are not found on any other miniature from this period. Also, the loose style with clear brushstrokes used in the sashes does not match that of the followers of the Firanzi-saz style.

Could Gesina be responsible for the alterations and the retouchings ? The technical analysis confirmed that the pigments used for the later additions were also present in other art works that are part of the album and that these pigments were widely used by seventeenth century Dutch painters. It is precisely this ubiquity that limits their

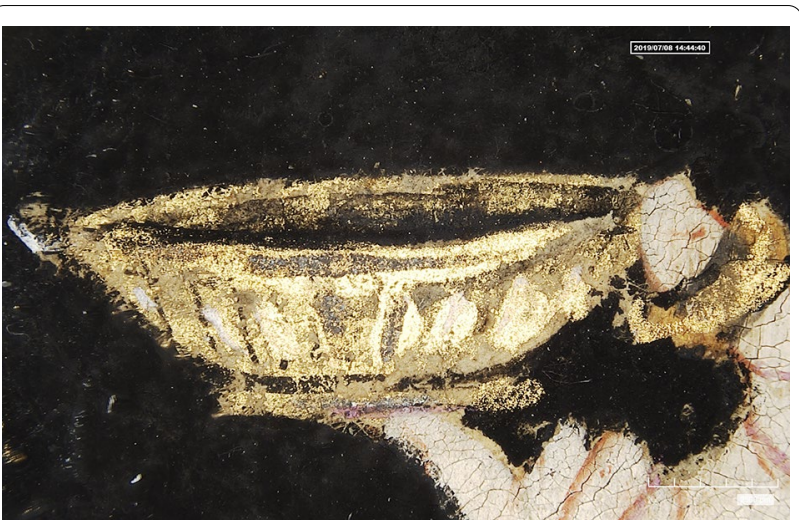

Fig. 22 Micrograph showing the cup and the handle. HIROX $\mathrm{RH}-2000,20 \mathrm{X}$

attribution to a specific artist. However, it is known that Gesina often made changes to the works of other artists in her scrapbook and stylistically, the sashes around the Iranian Youth's waist, are very close to the sashes in bright orange and blue that Gesina herself painted in other works in the album.

The hypothesis that Gesina touched up parts of the painting would explain the unusual drinking bowl in the Youth's right hand. Digital microscopy and MAXRF showed that this area was overpainted with gold paint (gold II consisting of gold and copper), together with orpiment, silver and a few small touches of calcite. The original appearance may have been similar to the Christie's miniature (Fig. 2d), which shows the young man holding a bowl and wearing a thumb or archers' ring, called kustubān in Persian. ${ }^{29}$ It is a piece of jewellery widely used in Islamic culture and often depicted in Iranian painting, designed to protect the thumb during archery. During the Safavid era it was a luxury ornament for the ruling elite and high-ranking military personnel. On the Christie's miniature the ring has a special protuberance intended to prevent the skin from rubbing against the bowstring. As the Rijksmuseum painting in its final form does not show this specific shape, it is possible that a Dutch artist, who had never seen such a ring, misunderstood the ornament and repainted it as a cup handle (Fig. 22). It would be unlikely that artists based in Iran would have made such an error.

Close examination showed that the original drawing was damaged and incomplete. In the album, other instances of drawings being pasted onto the pages and highlighted with framed lines can be found. This indicates

\footnotetext{
${ }^{29}$ For an example of a simple archer's ring see British Museum https://www. britishmuseum.org/collection/object/W_As-9930 and for a luxurious version see Victorian \& Albert Museum http://collections.vam.ac.uk/item/O94134/ thumb-ring-unknown/
} 
that it was a familiar practice for Gesina and that she could have operated in the same way for the Iranian Youth. In a hypothetical reconstruction of her actions, she might have pasted the miniature onto a page in the scrapbook, added a piece of paper to fill in the missing corner and continued to paint on the page itself to give it a rectangular format. Then she might have followed the rough outlines of the body and the clothes with a brush and also covered the feather and a part of the fluttering sash with dark paint. Finally, she could have added the feather and the white sash on the black paint and touched up the rest of the dress, the sashes, the collar, part of the turban and the sword. While in the absence of scientific evidence it is difficult to ascertain with certainty the hand of Gesina in the retouching of the damaged areas of the painting, it is altogether possible that she was also responsible for these interventions.

\section{Conclusion}

Scientific and historical research has revealed that the painting of the Iranian Youth is a unique artwork that has no precedent nor following. To the authors' knowledge, it is the only example of an Iranian miniature that has been completely redesigned by a seventeenth century European artist. Even if the analytical results left some questions unanswered, they enabled reconstructing parts of the genuine painting and its evolution in the Netherlands. By combining technical analysis and (art) historical evidence, the authors hypothesized the following: Gesina ter Borch acquired a very damaged original mid-seventeenth-century Iranian miniature made by an anonymous painter from the Isfahan School. She may have bought it more for its curiosity value than out of a personal interest in and admiration of Iranian art, as there is no other evidence to support the latter. When she pasted it into her album, she made changes and touched up the damaged areas. While the result now looks odd and even unappealing, the miniature in its final hybrid form remains a fascinating example of the artistic encounter between East and West.

\section{Abbreviations \\ FORS: Fibre optic reflectance; $\mu$-XRF: Micro X-ray fluorescence; MA-XRF: Macro $X$-ray fluorescence; IRR: Infrared reflectography.}

\footnotetext{
Acknowledgements

Benjamin Rous, coordinator at Netherlands Institute for Conservation + Arts + Science for editing and advising, Petria Noble, head of painting conservation for pigment sampling for lead isotope analysis, Ige Verslype, painting conservator for advising and facilitating access to analytical equipment, Idelette van Leeuwen, head of paper and photograph conservation at the Rijksmuseum, Ilona van Tuinen, curator for drawings at the Rijksmuseum Prentkabinet, Victor Gonzalez, assistant researcher (postdoc) at the Rijksmuseum for bringing his expertise in micro X-ray fluorescence, Simone Gaisbauer for running the FORS measurements, Mandana Barkeshli for her expertise in Iranian pigments, Forough Sajadi, PhD candidate at Warsaw University for sharing her knowledge in
}

Persian paintings, Willem Floor, Historian specialising in Safavid and Qajar Iran and Prof. Dr. Gareth R. Davies, Full Professor, Faculty of Science, Earth Sciences, VU Amsterdam, for his expertise in lead isotope analysis.

\section{Authors' contributions}

ACD coordinated the project, carried out the micro-XRF, FORS processing, IRR, HIROX imagery and wrote the first draft of the paper. ACD also brought her expertise in Persian paintings from the artistic and technical aspects. JH carried out the artistic and historical research and brought his expertise in Netherlandish painting from the seventeen century. LS carried out the macroXRF measurements and interpretation of the element mapping together with MA. LS contributed in the lead isotope methodology and sampling. PDI carried out the lead isotope analysis. All authors contributed to data interpretation, helped in designing and writing the paper, provided corrections to the manuscript. All authors read and approved the final manuscript.

\section{Funding}

Not applicable.

\section{Availability of data and materials}

The datasets used and/or analysed during the current study are available from the corresponding author on reasonable request.

\section{Declarations}

\section{Competing interests}

The authors declare that they have no competing interests.

\section{Author details}

${ }^{1}$ Utrecht, The Netherlands. ${ }^{2}$ Conservation \& Science Department, Rijksmuseum, Postbus 74888, 1070 DN Amsterdam, The Netherlands. ${ }^{3}$ History Department Rijksmuseum, Postbus 74888, 1070 DN Amsterdam, The Netherlands. ${ }^{4}$ Faculty of Science, Geology and Geochemistry, Vrije Universiteit Amsterdam, Amsterdam, The Netherlands. ${ }^{5}$ Department of Materials Science and Engineering, Delft University of Technology, Mekelweg 2, 2628 CD Delft, The Netherlands.

Received: 18 March 2021 Accepted: 18 August 2021

Published online: 25 September 2021

\section{References}

1. McNeil Kettering A. Drawings from the Ter Borch Studio Estate in the Rijksmuseum. 's-Gravenhage: Staatsuitgeverij; Catalogus van de Nederlandse tekeningen in het Rijksprentenkabinet, Rijksmuseum, Amsterdam. 1998:5:362-64 and 615-760.

2. De Hond J, Couvrat Desvergnes A, Sauvage L, Sajadi F, D'Imporzano P. An Iranian youth in an album from Zwolle. Rijksmus Bull. 2020;68:204-31.

3. Canby SR. The rebellious reformer: the drawings and paintings of Riza-yi Abbasi of Isfahan. London: I.B.Tauris; 1996. p. 9-18.

4. Thompson J, Canby SR (eds.). Hunt for paradise: court arts of Safavid Iran, 1501-76. Milan: Skira, London: Thames \& Hudson; 2003. pp 122-23.

5. Fetvaci E, Gruber C. Painting, from royal to urban patronage. In: Flood FB, Necipoglu G, editors. A companion to Islamic art and architecture. Hoboken: Wiley-Blackwell; 2017. p. 874-902.

6. Langer A. European influences on seventeenth-century Persian painting: of handsome Europeans, naked ladies, and Parisian timepieces, In Langer A, Exhib. cat. The fascination of Persia: The Persian-European dialogue in seventeenth-century art and contemporary art of Tehran. Zürich: Scheidegger \& Spiess; 2013 pp 170-237.

7. Graves SM, Junod B (eds). Treasures of the Aga Khan Museum: arts of the book and calligraphy, Exhib. cat. Istanbul: Sakip Sabanci Museum; 2010. pp 332-33, no.146.

8. Bronk H, Röhrs S, Bjeoumikhov A, Langhoff N, Schmalz J, Wedell R, et al. ArtTAX — a new mobile spectrometer for energy-dispersive micro X-ray fluorescence spectrometry on art and archaeological objects. Fresenius J Anal Chem. 2001;371:307-16. 
9. Alfeld M, Vaz Pedroso J, van Eikema HM, van der Snickt G, Tauber G, Blaas $J$, et al. A mobile instrument for in situ scanning macro-XRF investigation of historical paintings. J Anal At Spectrom. 2013;28:760-7.

10. Solé VA, Papillon E, Cotte M, Walter P, Susini J. A multiplatform code for the analysis of energy-dispersive $\mathrm{X}$-ray fluorescence spectra. Spectrochim Acta B. 2007;62:63-8.

11. Alfeld M, Janssens K. Strategies for processing mega-pixel X-ray fluorescence hyperspectral data: a case study on a version of Caravaggio's painting Supper at Emmaus. J Anal At Spectrom. 2015;30:777-89.

12. D'Imporzano P, Keune $K$, Koornneef JM, Hermens E, Noble P, Zuilen $K$, Davies JR. Micro-invasive method for studying lead isotopes in paintings. Archaeometry. 2020;62:796-809.

13. Fabian D, Fortunato G. Tracing white: a study of lead white pigments found in seventeenth-century paintings using high precision lead isotope abundance ratios. In: Kirby J, Nash S, Cannon J, editors. Trade in artists' materials: markets and commerce in Europe to 1700. London: Archetype publications; 2010. p. 426-43.

14. Fortunato G, Ritter A, Fabian D. Old Masters' lead white pigments: investigations of paintings from the 16th to the 17th century using high precision lead isotope abundance ratios. Analyst. 2005;130:898-906.

15. Keisch B, Callahan RC. Lead isotope ratios in artists'lead white: a progress report. Archaeometry. 1976;18:181-93.

16. D'Imporzano P, Batur K, Keune K, Koornneef JM, Hermens E, Noble P, van Zuilen, Davies GR. Lead isotopes heterogeneity in lead white: from lead white raw pigment to canvas. Microchem J. 2021;163:1-10.

17. Wolf S, Stos S, Mason R, Tite MS. Lead-isotope analysis of Islamic pottery glazes from Fustat, Egypt. Archaeometry. 2003;45:405-20.

18. Mirnejad H, Simonetti A, Molasalehi F. Origin and formational history of some $\mathrm{Pb}-\mathrm{Zn}$ deposits from Alborz and Central Iran: $\mathrm{Pb}$ isotope constraints. Int Geol Rev. 2015;57:463-71.

19. Faure G. Principles of isotope geology. London: Wiley; 1986.

20. Gulson B. Lead isotope in mineral exploration. Amsterdam, Oxford, New York, Tokyo: Elsevier; 1986.

21. Bazargani-Guilani K, Nekouvaght Tak MA, Faramarzi M. Pb-Zn deposits in Cretaceous carbonate host rocks, northeast Shahmirzad, central Alborz, Iran. Aust J Earth Sci. 2011;58:297-307.

22. Ehya F, Lotfi M, Rasa I. Emarat carbonate-hosted Zn-Pb deposit, Markazi Province, Iran: a geological, mineralogical and isotopic $(\mathrm{S}, \mathrm{Pb})$ study. J Asian Earth Sci. 2010;37:186-94.

23. Gilg HA, Boni M, Balassone G, Allen CR, Banks D, Moore F. Marble-hosted sulfide ores in the Angouran $\mathrm{Zn}$-(Pb-Ag) deposit, NW Iran: interaction of sedimentary brines with a metamorphic core complex. Miner Depos. 2006:41:1-16.

24. Mirnejad H, Simonetti A, Molasalehi F. Pb isotopic compositions of some $\mathrm{Zn}-\mathrm{Pb}$ deposits and occurrences from Urumieh-Dokhtar and SanandajSirjan zones in Iran. Ore Geol Rev. 2011;39:181-7.

25. Mousivand F, Rastad E, Meffre S, Peter JM, Solomon M, Zaw K. U-Pb geochronology and $\mathrm{Pb}$ isotope characteristics of the Chahgaz volcanogenic massive sulphide deposit, southern Iran'. Int Geol Rev. 2011;53:1239-62.

26. Batur K, Radić RI. Archaeological evidence of Venetian trade in colouring materials: the case of the Gnalić shipwreck. In: Haak Christensen A, Jager A, editors. Trading paintings and painters' materials 1550-1800, CATS Proceedings IV. London: Archetype publications; 2019. p. 111-20.

27. Barkeshli M. Paint palette used by Iranian masters based on Persian medieval recipes. Restaurator. 2013;34:101-33.

28. Knipe P, Eremin K, Walton M, Babini A, Rayner G. Materials and techniques of Islamic manuscripts. Herit Sci. 2018;6:55.

29. Purington N, Watters M. A study of materials used by medieval Persian painters. JAIC. 1991;30-2:125-44.

30. Muralha VSF, Burgio L, Clark RJH. Raman spectroscopy analysis of pigments on 16-17th c. Persian manuscripts. Spectrochim Acta A. 2012;92:21-8

31. Barkeshli M. Material technology and science in Manuscripts of Persian Mystical Literature. Manuscr Cult. 2015;8:187-214.

32. Hayez V, Denoël S, Genadry Z, Gilbert B. Identification of pigments on a 16th century Persian manuscript by micro-Raman spectroscopy. J Raman Spectrosc. 2004;35:781-5.
33. Anselmi C, Ricciardi P, Buti D, Romani A, Moretti P, Rose Beers K, et al. MOLAB ${ }^{\circledR}$ meets Persia: non-invasive study of a sixteenth-century illuminated manuscript. Stud Conserv. 2015;60(S1):85-92.

34. Ferrier RW. An English view of Persian trade in 1618. Reports from the Merchants Edward Pettus and Thomas Barker. J Econ Soc Hist Orient. 1976; 19-2: 182-214.

35. Porter Y. Cobalt dans le Monde Iranian (IX-XVle siècles). Notes sur son utilisation en céramique et son commerce. TAOCI. 2000;1:5-14.

36. Matin M, Pollard M. Historical accounts of cobalt ore processing from the Kashan Mine, Iran. Iran (Lond). 2015;53:171-83.

37. Floor W, West FitzHugh E. Cobalt. Encyclopaedia Iranica, V;8:873-75. https://iranicaonline.org/articles/cobalt-sang-a-lajavard-blue-stone-alsoapplied-to-lapis-lazuli-and-ultramarine-lajavard-e-kasi-ceramic-blue-la.

38. Holakooei P, Karimy AH. Micro-Raman spectroscopy and X-ray fluorescence spectrometry on the characterization of the Persian pigments used in the pre-seventeenth century wall paintings of Masjid-i Jāme of Abarqū, central Iran. Spectrochim Acta, Part A. 2014; 134:419-427.

39. Berrie BH. Mining for color: new blues, yellows, and translucent paint. Early Sci Med. 2015;20:308-34.

40. van Loon A, Noble P, de Man D, et al. The role of smalt in complex pigment mixtures in Rembrandt's Homer 1663: combining MA-XRF imaging, microanalysis, paint reconstructions and OCT. Herit Sci. 2020;8:90.

41. Floor W. Dutch-Persian relations. Encyclopaedia Iranica, VII;6: 603-613. http://www.iranicaonline.org/articles/dutch-persian-relations.

42. Cabelli D, Mathews TF. The Palette of Khatchatur of Khizan. J Walters Art Gallery. 1982;40:37-40.

43. Khandekar N, Eremin, K, Knipe P. The New Science and Technology behind Art Conservation, in Science \& South Asia The Lakshmi Mittal and Family South Asia Institute at Harvard University, Harvard University, 2018 : 56-61.

44. Darrah JA. Connections and coincidences: three pigments. In: Arie W, Erma H, Marja P, editors. Historical painting techniques, materials and studio practice. Marina del Rey: The Getty Conservation Institute; 1996. p. 70-7.

45. Baidya AS, Sen A, Pal DC. Textures and compositions of cobalt pentlandite and cobaltian mackinawite from the Madan-Kudan copper deposit, Khetri Copper Belt, Rajasthan, India. J Earth Syst Sci. 2018;127:56.

46. Newman R. In: S.L. Diba, M. Ekhtiar (editors). Royal Persian Paintings: The Qajar Epoch: 1785-1925, Brooklyn Museum of Art, New York; 1998. pp 283-87.

47. Matin M, Pollard M. From ore to pigment: a description of the minerals and an experimental study of cobalt ore processing from the Kashan Mine, Iran. Archaeometry. 2017;59:731-46.

48. De Hond J. Cornelis de Bruijn (1652-1726/27): a Dutch painter in the East. In: van Gelder GJ, de Moor E, editors. Orientations series Eastward Bound: Dutch ventures and adventures in the Middle East. Brill: Leiden; 1994. p. $51-80$.

49. Matthee RP. Iran's relations with Europe in the Safavid Period: diplomats, missionaries, merchants, and travel. In: In Langer A, Exhib. cat. The fascination of Persia: The Persian-European dialogue in seventeenth-century art and contemporary art of Tehran. Zürich: Scheidegger \& Spiess; 2013. pp 6-39.

50. Langer A. European influences on seventeenth-century Persian painting: of handsome Europeans, naked ladies, and Parisian timepieces, In Langer A, Exhib. cat. The fascination of Persia: The Persian-European dialogue in seventeenth-century art and contemporary art of Teheran. Zürich: Scheidegger \& Spiess; 2013. pp 170-237.

51. Schwartz G. Between court and company: Dutch artists in Persia. In Langer A, Exhib. cat. The fascination of Persia: The Persian-European dialogue in seventeenth-century art and contemporary art of Tehran. Zürich: Scheidegger \& Spiess; 2013. 152-196.

52. Floor W, Sajadi F. Jan Lucasz van Hasselt: a Dutch Painter in Safavid Isfahan, Iran. Stud. 2020. https://doi.org/10.1080/00210862.2020.1787127.

\section{Publisher's Note}

Springer Nature remains neutral with regard to jurisdictional claims in published maps and institutional affiliations. 